Portland State University

PDXScholar

Engineering and Technology Management

Faculty Publications and Presentations

8-1-2007

\title{
A Decision Support Model for Project Manager Assignments
}

\author{
Peerasit Patanakul \\ Portland State University \\ Dragan Milošević \\ Portland State University
}

Timothy R. Anderson

Portland State University, tim.anderson@pdx.edu

Follow this and additional works at: https://pdxscholar.library.pdx.edu/etm_fac

Part of the Engineering Commons

Let us know how access to this document benefits you.

\section{Citation Details}

Patanakul, Peerasit; Milošević, Dragan; and Anderson, Timothy R., "A Decision Support Model for Project Manager Assignments" (2007). Engineering and Technology Management Faculty Publications and Presentations. Paper 22. http://archives.pdx.edu/ds/psu/9255

This Post-Print is brought to you for free and open access. It has been accepted for inclusion in Engineering and Technology Management Faculty Publications and Presentations by an authorized administrator of PDXScholar. Please contact us if we can make this document more accessible: pdxscholar@pdx.edu. 


\title{
A Decision Support Model for Project Manager Assignments
}

\author{
Peerasit Patanakul*, Dragan Z. Milosevic**, Timothy R. Anderson**
}

* At the time of publication: Wesley J. Howe School of Technology Management, Stevens Institute of Technology

*Current affiliation: Black School of Business, Pennsylvania State University, Erie

** Department of Engineering and Technology Management, Portland State University

INDEX TERMS: Project assignment methodology, decision support model, integer programming model, project assignment process, project assignment criteria

ACKNOWLEDgement: The authors would like to thank Dr. Dundar Kocaoglu, Dr. Wayne Wakeland, and Dr. Robert Eder for their comments and assistance on this research. They also appreciate the information and support from all of the research participants, including Dr. Hans Thamhain, Dr. Matthew Liberatore, Dr. Preston Smith, John Patton, Louise Roberts, Tom Maxwell, and Scott Peterson. The authors also wish to thank the Editors and the referees for their comments to improve this paper. 


\section{A Decision Support Model for Project Manager Assignments}

ABSTRACT - The question, "How to assign projects to project managers?" is considered to be one of the most important questions in project management. Nevertheless, methods to answer this question have not yet been sufficiently addressed in the literature. In practice, even though the question is rather common, practitioners still seek an effective project assignment methodology — especially for the assignments of project managers of multiple, concurrent projects, such as a project manager of new product development projects in typical high-tech industries. To respond to this question, we performed an inductive study to develop a theoretical framework for project assignments, including some significant assignment criteria and processes. We found that to be effective in project assignments, management should consider strategic elements of the organization in project prioritization, project requirements and competencies of project managers in project manager-to-project matching, and some organizational/personal limitations regarding the assignment. An optimization model was developed to apply this framework. This model can assist in assigning projects to project managers for the better performances of projects, project managers, and the organization.

\section{INTRODUCTION}

In many organizations, the project assignment of projects to project managers is often considered by management to be a major challenge $[1,2]$. It must be done appropriately since assigning the right project manager to the project is one of the critical success factors in project management [3-5]. Despite the fact that project assignment is important and inappropriate assignments may lead to a decrease in the project success rate, which may negatively impact the organizational performance, the research in this area is fairly limited. Several researchers, 
however, have proposed assignment methodologies [6-8], which use project requirements and project managers' skills as assignment criteria. Our concern is that assigning projects by using only these criteria may not be sufficient. We argue that the extant literature has established the fact that project manager assignments affect the performance of projects, project managers, and the organization. Other criteria, e.g. strategic importance of projects to the organization and the organizational limitations regarding the time availability of a project manager, etc. should be included.

In fact, considering these additional criteria in the assignment is especially critical in current business practices where some organizations consider projects (mostly new product development) as the engines of corporate success, survival, and renewal [9]. Usually, these projects are selected to enhance the organizational performance [10], with an eye to selecting those that will provide the highest value to the company's strategy [11]. Assigning these projects to project managers without paying attention to the strategic importance of the projects or the impact of projects on the performance of an organization may eventually make the organization vulnerable. Also, in many organizations, several project managers lead multiple, simultaneous projects $[10,12-15]$. Assigning projects to them without considering, e.g. their availability, may overload project managers, which may eventually cause project failures [14].

The critical importance of project assignments and the limited information thereof in the literature led us to study a process and criteria for project assignment used by a number of leading companies in order to develop a theoretical framework, including a systematic process and methodology for project assignment. We believe that the framework will lead to effective project assignments, which will in turn impact project success and eventually the performance of an organization. 


\section{BACKGROUND}

Despite the limited amount of research in this area, we were able to classify the literature into two streams: criteria and methodologies for project assignments as shown in Exhibit 1.

\section{Insert Exhibit 1 around here}

\section{a) Criteria for project assignments}

Although the first stream of literature is not specific to a project assignment context, it indirectly recognizes the skill sets of project managers and project requirements as assignment criteria. In this stream, several studies propose successful project managers' skill sets [16-22] and often imply that those skills can be used as criteria in an assignment process. In general, the skills can be categorized into technical, administrative/process, human/interpersonal, and business/strategic skills. Note that many recent studies emphasize the significance of the human/interpersonal and business/strategic skills over the technical skills [26]. This is consistent with the influential studies of Katz [27] and Shenhar and Thamhain [28], which claim that as the level of administrative responsibility of managers grows higher, so does the importance of their human skills over their technical skills. Besides the skill sets, project characteristics are also recognized as important assignment criteria. Those characteristics can be derived from the complexity of projects, project size, project duration, level of technological uncertainty, interdependencies and interactions among projects, the experience and sophistication of clients, and the degree of stakeholder involvement, etc. [23, 24]. Shenhar [25] emphasizes the characteristics such as technological uncertainty, system complexity and pace are important factors determining management styles of project managers. 
As previously mentioned, it may be insufficient if management uses only skill sets of project managers and project requirements as assignment criteria. The strategic importance of the projects and some organizational limitations regarding project assignments should be included. To understand the strategic importance of the project, one way to do so may be to deploy the organizational strategic elements in project prioritization. Although these elements (e.g. organizational goals) have been extensively recommended for use in project selection, to the best of our knowledge, they have almost never been recommended as criteria for the process of project assignments. From the literature, the organizational goals suggested for use in project selection can be grouped into the goals related to business, operations, and technology aspects [29-35]. In terms of organizational limitations, several authors recognized their importance in project management, although not specifically in terms of project assignments. These limitations include the organization's resource capacity [31,36], interdependencies and interactions among projects [37,38], and a project manager's workload [14]. These organizational goals and limitations should also be parts of project manager assignments and therefore:

Conceptual Thinking 1: Organizational strategic elements and limitations are likely to be used as additional criteria for project assignments.

\section{b) Methodologies for project assignments}

In the second stream of the literature, only a few researchers proposed methodologies for assigning a project to a project manager. These methodologies base project assignments on project requirements and the project manager's skills.

Adams, et al. [6] propose a contingency approach based on attribute matching. They suggest that management should 1) identify the demands of the project according to factors regarding economic, organizational, technological, and behavioral characteristics of a project. 2) 
Then, factors are prioritized according to their expected importance. 3) Project manager candidates are subjectively rated in terms of their abilities to cope with problems associated with the identified factors. 4) The final step of project manager selection is choosing a project manager who has capabilities matching the expected demands of the project.

Similar to the study of Adams, et al. [6], Hauschildt, et al. [7] proposed a methodology for selecting a project manager. They suggest that 1) project managers should be classified into different types (the project star, the promising newcomer, the focused creative expert, and the uncreative decision maker) based upon their abilities (organizing under conflict, experience, decision-making, productive creativity, etc.). 2) Management should identify the types of projects that each type of project manager can successfully lead. 3) Project managers are assigned to lead only the type of projects that they can successfully lead. However, Hauschildt, et al. [7] state that the types of project managers they used may not have universal validity.

Mian and Dai [8] also proposed a methodology for project assignments based on project requirements and a project manager's background. This methodology utilized concepts of the analytic hierarchy process (AHP) to assign projects to project managers based on the criteria: administrative and supervisory skills, technical knowledge, and personal abilities of project managers.

In summary, the methodologies proposed in the literature for assigning projects are based solely on project requirements and skills of project managers. Since the organization's strategic characteristics and the resource capacity of project managers, are not part of the assignment methodologies, these approaches may not be applicable for project assignment in many organizations - this is particularly true of the challenge in high technology industries, where managers are frequently assigned multiple projects to manage. Hence: 
Conceptual Thinking 2: The project assignment process and methodology are likely to include additional steps that incorporate organizational strategic elements and limitations in making assignment decisions.

\section{RESEARCH APPROACH}

In order to develop a systematic process and methodology for project manager assignments that are applicable to the current project management environments, we started our study by exploring the process and criteria in the current environments. Conceptual Thinking 1 $\& 2$ helped us frame our research. Then, we used the emerging processes and criteria to guide the development of a methodology for project manager assignment as shown in Exhibit 2.

\section{Insert Exhibit 2 around here}

\section{A. Exploring the processes and criteria for project manager assignments}

Since there was relatively little empirically grounded research in this area of multiple project assignments, we used a case study research approach $[39,40]$ coupling with Delphi method [41] to determine the necessary process and criteria for project assignments. Exhibit 2 summarizes the research design and process in this step. The details of the case study research design and process are described in detail in $[42,43]$.

\section{B. Developing a methodology for project manager assignments}

Based on the emerging process and criteria from the case analysis, we developed a conceptual model for project assignment. An assignment methodology was then developed using the concepts of general assignment problems (GAP), an integer programming model [44]. 
We developed this model to be a decision-aid tool for project manager assignments and validated it with the information from a participating company. Although GAP has been used in many applications [45-49], it has not been used in project manager assignment problems.

\section{RESEARCH RESULTS}

In our study, the step of exploring the process and criteria was done rigorously in order to understand the current process and develop an integrated list of criteria for project manager assignments. The summary is discussed in the following section and in more detail in [42, 43]. In this paper, the concentration is on our proposed methodology for project manager assignments.

\section{A. Process and criteria for project manager assignments}

Evidence from the case studies shows that project prioritization, project manager-toproject matching, and recognition of limitations are three main steps in the process of project manager assignments. For the assignment criteria, the organizational strategic elements, project requirements, competencies of project managers, and organizational/personal limitations are four groups of criteria associated with the process.

The case studies revealed that before projects are assigned to project managers, management prioritizes projects to understand their importance to the organization, i.e. the degree to which they contribute to the accomplishment of the organization's strategic elements. The elements such as organizational mission and goals are used in this prioritization step. In fact, these elements have been widely used for project selection but to the best of our knowledge, they have not been proposed for project prioritization in project manager assignments. 
After identifying the importance level of a project, preferably, a strategically important project will be assigned to a skilled project manager whose competencies are well matched to the project requirements. This leads to the next step in the assignment process: project manager-toproject matching. In this step, the project's requirements have to be identified. In addition, the competency levels of project managers have to be assessed to recognize those whose competencies correspond to the project's needs. We found that the project assignment criteria in a group of project requirements should include the criteria such as risk level, technology novelty, schedule criticality, task complexity, etc. In terms of the competencies of project managers, the criteria can be categorized into technical, administrative/process, intrapersonal, interpersonal, business/strategic competencies, and multiple-project management competencies. The first four groups of competencies are consistent with the extant literature. These competencies help project managers lead each project individually. The group of multiple-project management competencies is new to the literature. These competencies, e.g. interdependency management, multitasking, and interproject process, help project managers coordinate simultaneous projects, see Patanakul and Milosevic [50] for more detail.

Besides considering strategic elements, project requirements, and competencies of project managers, the research evidence shows that organizational/personal limitations in project manager assignments have to be recognized. As discussed previously, some of these limitations have been mentioned in the literature. However, they are not specific to project manager assignments. One example of limitations that we found is the resource capacity of a project manager. A project should be assigned to a project manager if she is available to take on an additional project. Besides the resource capacity, criteria such as the experience of project managers in managing multiple projects and their career path, the interdependencies among 
projects, and preference of management (degree of trust) should also be considered when assigning projects to project managers.

\section{B. Methodology for project manager assignments}

In this study, we developed an optimization model (an integer-programming model) as a methodology for project manager assignments. The objective function of the model was developed by considering project priorities and levels of matching between project managers and projects. The mathematical constraints were developed based on both organizational and personal limitations. Exhibit 3 shows a theoretical framework for project manager assignments, an integration of a process, criteria, and methodology (an integer-programming model).

\section{Insert Exhibit 3 around here}

\section{a) The objective function}

$$
\operatorname{Max} \sum_{i=1}^{n} \sum_{j=1}^{m} \sum_{k=1}^{o}\left(\alpha_{i j k} G_{k} V_{j k} W_{i j} X_{i j}\right)
$$

The objective function was developed based on the evidence from case studies that a strategically important project $j\left(V_{j}=\sum_{k=1}^{o} G_{k} V_{j k}\right.$, see Exhibit 4) should be assigned to a skilled project manager $i$ whose competencies meet the project requirements $\left(W_{i j}\right)$, the project prioritization and project manager-to-project matching steps. The function also accommodates the possibility of reassignment of existing projects by recognizing the effectiveness of a project manager in managing discontinuity in a project in the case of the reassignment $\left(\alpha_{i j k}\right)$. We found 
from the case study that in some situations where skilled project managers are not available for the new assignments, management may decide to release them from their existing projects so that they will have resource availability to take on the new important projects. Those existing projects are put up for reassignments. The drawback of this approach is the existing projects that are assigned to other project managers may end up with some downsides, e.g. project delay, cost overrun, or quality problems. A cause of these downsides may be the discontinuity in management because of changing the project manager [10] and their magnitude may depend on how effectively the new project manager manages the project during this transition period. On the other hand, if management decides not to free up the skilled project managers and assigns the new strategically important projects to the less skilled project managers who are available, these managers may not be able to manage the new projects effectively. This may result a negative impact on the project performance and eventually the performance of the organization.

\section{Insert Exhibit 4 around here}

In the objective function:

$>\alpha_{i j k}$ represents the coefficient of effectiveness of project manager $i$ in managing project $j$ 's contribution to goal $k$ when there is a discontinuity in the management of project $j$ (reassignments of existing projects). The value of this coefficient is between 0 and 1. A value of 0.0 represents a complete failure in discontinuity management while a value of 1.0 indicates full effectiveness as if no discontinuity has occurred. This coefficient of effectiveness is one of the important factors determining a reassignment decision. See Appendix A for more explanation. 
$G_{k}$ and $V_{j k}$ represent the consideration of the strategic importance of the projects in the assignment. We define strategically important projects as those that provide major contributions to the organizational mission. We utilize a decision hierarchy to prioritize the project. From the hierarchy (see Exhibit 4), $G_{k}$ is a matrix representing the relative contribution of organizational goal $k$ to the organizational mission, and $V_{j k}$ is a matrix representing the relative contribution of project $j$ to organizational goal $k$ (organizational strategic elements). $G_{k}$ and $V_{j k}$ can be quantified by using a pairwise comparison method [51, 52], details are in Appendix A.

$>W_{i j}$ represents the correspondence level between project manager $i$ and project $j$ or the project manager-to-project matching score based on project requirements and competencies of project managers. From the case study portion of our research, we found that the competencies often used are in the groups of technical, administrative/process, intrapersonal, interpersonal, and business/strategic competencies. See Appendix A for the quantification of $W_{i j}$

$X_{i j}$ represents a binary decision variable. If project $j$ should be assigned to project manager $i$, $X_{i j}$ would be equal to 1 . This assignment model can be applied to assign both new and existing projects.

\section{b) The mathematical constraints}

The mathematical constraints were formulated from the criteria regarding organizational/personal limitations. This represents the recognition of the limitations step in the assignment process (see Exhibit 3). The major constraints found in this study are 1) resource 
availability, 2) project-type-mix, 3) project-phase-mix, 4) maximum number of projects, 5) special requirements, 6) fixed assignment, and 7) project interdependency.

\section{i. Resource Availability Constraints}

$$
\sum_{j=1}^{m} D_{i j} X_{i j}+S_{i} \leq A_{i} \quad \forall i
$$

This important group of constraints was developed to ensure that a project manager will not have excessive workload after the assignment is made. In other words, project $j$ can only be assigned to project manager $i$ if the project manager has sufficient time availability $\left(A_{i}\right)$. Two time demands upon the project manager are modeled. The first is the project's individual time demand $\left(D_{i j}\right)$. The second time demand is a penalty function to account for the loss in productivity due to multitasking (switchover-time loss [53]) between multiple projects $\left(S_{i}\right)$. Even though the switchover-time loss has not been discussed extensively in the literature and has mostly been ignored in practice, we consider it as a significant portion of time that a project manager of multiple projects spends.

In this set of constraints, the parameters $D_{i j}$ and $A_{i}$, are estimated over the time period or planning horizon, e.g. three months. In other words, these parameters are the predicted future values. The values of $S_{i}$ come from functions of decision variables, discussed later.

$D_{i j}$ represents the time demand of project $j$ for project manager $i$ (person-hours per time period). Since project managers spend different amounts of time on managing projects depending on their level of experience, the time demand has to be estimated for each project manager. However, instead of estimating the time demand for each project and each project manager, a decision maker can estimate it based on the type of project (e.g. breakthrough, platform, and derivative), the phase of project (e.g. conceptual/planning, execution, and termination), and level of project manager (e.g. level 1 to 3, junior to senior). The result of 
this estimation would be, for example, the time demand of a platform project in its conceptual phase if assigned to project manager level 1 is 216 person-hours per 12 -week horizon. The time demand would be equal to 120 person-hours if the project is assigned to project manager level 3 .

$A_{i}$ represents the resource availability of project manager $i$ (person-hours per time period).

$$
A_{i}=E_{i}-L_{i}
$$

$>E_{i}$ is the effective capacity of project manager $i$ (person-hours per time period). This capacity indicates the total time a project manager spends on projects after taking out non-project work or overhead time, e.g. administrative and vacation [54]. In the case of a 40-hour work week, the effective capacity of a project manager may be estimated as 32 hours with an assumption of 8 hours (20\%) of non-project work or overhead time. For a 12-week horizon, the effective capacity of a project manager would be 516 hours.

$L_{i}$ is the existing workload of project manager $i$ (person-hours per time period). This parameter indicates a future workload of a project manager from the existing projects that the project manager currently leads (exclude the future workload from the existing project's potential for reassignment). To estimate $L_{i}$, the same concept of project type, project phase, and level of project manager can be applied.

$S_{i}$ represents the switchover-time loss of project $i$ (person-hours per time period). It is the loss in project managers' capacity when switching from the issues of one project to the next project (multitasking). In this study, $S_{i}$ was estimated from the total number of projects that a project manager leads. Based on the information from Kapur International [55], the estimation of the switchover-time loss is shown in Exhibit 5. 


\section{Insert Exhibit 5 around here}

Note that there are several ways to formulate the mathematical equations representing this data. Following is one of the possible ways.

$$
S_{i}=1.5 Y_{i}+4.5 Z_{i} \quad \forall i
$$

Where:

$$
\begin{gathered}
S_{i}=\text { Switchover time-loss of project manager } i \text { (person-hours per time period) } \\
Y_{i}=\text { Number of projects in excess of one managed by project manager } i \\
Z_{i}=\text { A binary decision variable indicating whether or not project manager } i \text { is } \\
\quad \text { managing more than one project simultaneously }
\end{gathered}
$$

While conceptually simple, $Y_{i}$ and $Z_{i}$ are functions of both the number of preexisting projects managed by project manager $i\left(n_{i}\right)$ and the number of projects assigned to project manager $i\left(\sum_{j=1}^{n} X_{i j}\right)$. Therefore, incorporating this into the model requires some extra complexity as described below.

$n_{i}=$ Total number of existing projects under the responsibility of project manager $i$, not subject to potential reassignment

$X_{i j}=$ Decision variable representing the assignment of project $j$ to project manager $i$ (new assignment of project manager $i$ )

$N_{i}=$ Total number of projects under the responsibility of project manager $i$ (existing projects and new assignment) or

$$
N_{i}=\sum_{j=1}^{n} X_{i j}+n_{i} \quad \forall i
$$


$\gamma_{i}=$ Binary decision variable, and

$$
\begin{aligned}
& \gamma_{i} \quad \leq 1-0.25 N_{i} \quad \forall i \\
& Y_{i}= N_{i}+\gamma_{i}-1 \quad \forall i \\
& Z_{i}= \text { Binary decision variable, and } \\
& 4 Z_{i}-Y_{i} \geq 0 \\
& \\
& Z_{i}-Y_{i} \leq 0
\end{aligned}
$$

$\gamma_{i}$ is a binary decision variable, formulated to prevent $Y_{i}$ from being equal to negative one (-1), when $N_{i}$ is equal to 0 (if $Y_{i}$ is equal to -1 , the constraints $Z_{i}-Y_{i} \leq 0$ and $Z_{i}$ is a binary decision variable will be violated, leading to an infeasible solution). The coefficient of $Z_{i}$ in Equation 2.6 can be set as the maximum number of projects that a project manager can lead. Based on the information available in Exhibit 5, the coefficient is set as 4. Also, the coefficient 0.25 of $N_{i}$ in Equation 2.4 is the reciprocal of the maximum number of projects (set as 4 in this example). In practice, each organization should develop its own switchover-time loss equations based on its historical data. However, Equations 2.2 to 2.7 were developed to demonstrate how to apply the switchover-time loss to the resource availability constraints.

\section{ii. Project-type Mix Constraints}

We found from our study that often management does not assign several projects of a certain type for a project manager to lead at the same time. The reason may be that the complexity in scope and the uncertainty in technology of those projects limit the project manager from managing them effectively. To replicate this consideration, we developed a set of projecttype mix constraints, (3), as an extension of the resource availability constraints to represent the limitations regarding the types of projects that a project manager can simultaneously lead. 


$$
\sum_{j=1}^{m} P P_{j} X_{i j}+E P P_{i} \leq M P P_{i} \quad \forall i
$$

For project manager $i$, the total number of projects of a certain type (e.g. platform new product development project, $P P)$ from both the new assignments $\left(P P_{j} X_{i j}\right)$ and the existing assignments $\left(E P P_{i}\right)$ cannot exceed the maximum number of platform projects that project manager $i\left(M P P_{i}\right)$ can effectively lead at one time. $P P_{j}$ is a binary data $\left(P P_{j}=1\right.$; if project $j$ is a platform project or $P P_{j}=0$; if project $j$ is not a platform project). Since the constraints in this group measure resources by the unit of the number of projects at only the time of assignment, they are more static than the constraints in the previous group (2). However, they are easier to quantify.

\section{iii. Project-phase Mix Constraints}

$$
\sum_{j=1}^{m} C P_{j} X_{i j}+E C P_{i} \leq M C P_{i} \quad \forall i
$$

This group of constraints represents the limitations regarding the number of projects in certain phases that a project manager can simultaneously lead. We found evidence that some project managers cannot lead more than two projects in the conceptual and development phases since these phases require more attention from a project manager than the other phases. We then proposed that for project manager $i$, the total number of projects in conceptual and development phases, for example, both from the new assignments $\left(C P_{j} X_{i j}\right)$ and the existing assignments $\left(E C P_{i}\right)$, cannot exceed the maximum number of projects in conceptual and development phases that project manager $i\left(M C P_{i}\right)$ can effectively lead at the same time. $C P_{j}$ is a binary data value $\left(C P_{j}=1\right.$ if project $j$ is in the conceptual or developmental phase and $C P_{j}=0$ if project $j$ is not is in a conceptual or developmental phase). 


\section{iv. Maximum Number of Project Constraints}

$$
\sum_{j=1}^{m} X_{i j}+E_{i} \leq M_{i} \quad \forall i
$$

This is another group of resource capacity constraints representing the limitations regarding the total number of projects that a project manager can simultaneously lead. In some organizations, management sets the maximum number of projects assigned to each project manager. The reason is that management does not want to load their project managers up to the point that the project managers cannot be effective. In other words, for project manager $i$, the total number of projects from both the new assignments $\left(X_{i j}\right)$ and the existing assignments $\left(E_{i}\right)$ cannot exceed the maximum number of projects that project manager $i$ can simultaneously lead effectively $\left(M_{i}\right)$.

\section{v. Special Requirement Constraints}

$$
\sum_{i=1}^{n} S C_{i j} X_{i j}=1 \quad \forall j \in\{\text { Projects with special requirements }\}
$$

This group of constraints was developed to reflect the degree of trust in project managers by stakeholders. They reflect the situations where special project $j$ has to be assigned to project manager $i$ who possess specific competencies to lead project $j$ to its success. $S C_{i j}$ is a binary data $\left(S C_{i j}=1\right.$ if project manager $i$ has special competencies to respond to special project $j$ or $S C_{i j}=0$ if project manager $i$ does not have special competencies to respond to special project $j$ ). For this group of constraints, we can formulate it in such a way that special project $j$ is assigned to any skilled project manager in a predetermined group. 


\section{vi. Fixed Assignment Constraints}

$$
X_{i j}=1 \quad \forall i, j \in\{\text { Fixed project assignments }\}
$$

This group of constraints represents some special situations where project manager $i$ requests to lead project $j$ according to his personal preference, or management would like to assign a project to him for skills or knowledge development, etc. This group of constraints is more strict than the special requirement constraints since it forces a specific assignment, e.g. project A has to be assigned to project manager A.

Along the same lines as the above constraints, in some situations, project manager $i$ is not allowed to lead project $j$. For example, a customer does not want project manager $i$ to lead project $j$. The mathematical expression of these constraints is as follows.

$$
X_{i j}=0 \quad \forall i, j \in\{\text { Unallowable project assignments }\}
$$

\section{vii. Project Interdependency Constraints}

$$
\begin{gathered}
X_{i j}=X_{i k} \quad \forall i,(j, k) \in\{\text { A set of projects } j \text { and } k \text { such that projects } j \text { and } k \text { must } \\
\text { be assigned to the same project manager } i\}
\end{gathered}
$$

This group of constraints is developed to accommodate the fact that some projects $(j$ and $k$ ) must be assigned to project manager $i$ because of the interdependencies and interactions between projects. Assigning these projects to the same project manager leads to better project management and project success. 
viii. Technical Constraints

$$
\sum_{i=1}^{n} X_{i j}=1 \quad \forall j
$$

Each project must be assigned, and it can be assigned to only one project manager. In the case that some projects do not have to be assigned at this time of assignments, the constraints in Equation 10 should be adjusted to " $\sum_{i=1}^{n} X_{i j} \leq 1 \quad \forall j . "$

$$
\begin{array}{ll}
X_{i j} & =0,1 \text { binary decision variables } \\
Z_{i} & =0,1 \text { binary decision variables } \\
\gamma_{i} & =0,1 \text { binary decision variable }
\end{array}
$$

The constraint specifies $X_{i j}, Z_{i}$, and $\gamma_{i}$ as zero and one binary decision variables.

\section{c) The Assumptions and Limitations of the Model}

The model has major assumptions and limitations as follows:

Function of time: The model assigns projects to project managers by using the total time demand of a project and the total time availability of a project manager in a planning horizon. It assumes that after assignments, project managers have an opportunity to prioritize and organize their tasks to balance their workload in that planning horizon. Therefore, the project demands and resource availability of project managers in Equation 2 are not formulated as functions of time.

Switchover-time loss equations: The switchover-time loss is incorporated in the model as a function of the number of projects at the time of assignments. This assumes that $a$ 
project manager continuously has the same number of projects to lead within that planning horizon. In addition, the model assumes a linear relationship between the number of projects and the switchover-time loss when the number of projects is greater than one (Equation 2.2); also based on the available information from [55], it assumes that the complexity of projects and the experience level of project managers do not have any influence on the switchover-time loss. Note that Equations 2.2 to 2.7 are presented only to show the possibility of integrating the switchover-time loss into project assignments. In practice, each organization should be able to develop its own switchover-time loss equations.

\section{The decision hierarchy can suffer from rank reversal caused by the introduction or}

deletion of new alternatives: While intending to keep the model as flexible as possible, we believed that if there are any changes in the list of goals or projects, new pairwise comparisons should be performed with respect to those changes. In practice, the organizational mission and goals do not change frequently. If those changes occur, they represent changes in the company's direction and deserve much attention. Performing new comparisons should not be a major concern. The same approach should be applied to the list of projects to be assigned. The priority of projects is time/situation dependent. A new set of comparisons should be performed if there is any change to the list of projects or if we evaluate the project at a different time.

\section{An Example}

Besides testing the validity of the model internally based on various scenarios, etc., we executed and validated the model with the information from a participating company, shown 
here as an example. We found that this validation strategy was appropriate since in addition to the internal validation to ensure that the model worked properly as intended, the in-depth external validation with a company helped assure the applicability of the model in the real-life context.

At the time of this research, the participating company was a technology-driven organization in a high-tech industry. It was a worldwide leader in digital technology and solutions. With its emphasis on using product development as an engine of growth, the company produced the industry's most comprehensive lines of products. In terms of project management, the company implemented 30-40 product development projects per year, ranging from derivative to breakthrough product development projects (less than $\$ 1$ million to more than $\$ 5$ million budgeted and 4-24 months in duration). It had 12 project managers who on average simultaneously led 2 to 4 projects.

The model that we built for the company was used to assign six projects to six project managers (See Exhibit 6 and 7). Initially, this assignment decision took place because the company had to implement a new project (P6). Based on the original assignments, determined by the director of project management group without using any decision-aided tool, every project manager (besides PM F) was leading two projects at that time (See Exhibit 7). With the need to implement P6, the assignment alternatives were 1) assigning P6 right away to a junior project manager, PM F, who was available or 2) rearranging the existing assignments so that P6 and other projects would be assigned to the appropriate project managers. The director of the project management group considered rearranging the existing assignments to be a better alternative. To do so, the director freed up P1 to P5 from PM A to PM E to create the availability of those project managers (See Exhibit 7). The model was therefore developed to assign six projects (one 
new and five existing projects) to six project managers (five of them were the project managers of those existing projects). As shown in Exhibit 6, those six projects had different levels of importance to the organization, they had different levels of requirements, they were of different types, and they were in different phases of implementation. In addition, the project managers had different level of competencies, workload, and experience ranging from junior to senior project managers (See Exhibit 7). This assignment situation was challenging because it involved the reassignment of five existing projects. However, it helped us test the capability of the model with regards to the potential reassignments.

\section{Insert Exhibit 6 around here}

\section{Insert Exhibit 7 around here}

\section{A. Project prioritization}

Project prioritization is one of the mediating steps in the assignment process (Exhibit 3). To prioritize projects, a decision hierarchy was constructed as shown in Exhibit 8. A questionnaire was developed to gather organizational mission and goals (strategic elements) to be placed on the first and second levels of the hierarchy. The third level contains projects to be assigned. After the director performed pairwise comparisons, a software program was used to quantify the values of $G_{k}$ and $V_{j k}$ (shown in Exhibit 8). Since every goal equally contributes to the organization mission, the value of $G_{1}$ is equal to the values of $G_{2}, G_{3}$, and $G_{4}(25 \%)$. However, the contribution of each project to the goals is different. In this example, Project 2 contributes $16.67 \%$ to the accomplishment of Goal $3\left(V_{23}=16.67\right)$. 


\section{Insert Exhibit 8 around here}

From Exhibit 8, the priority of projects to the organization can be calculated from the multiplication of matrix $G_{k}$ and matrix $V_{j k}$. By doing so, we found that $\mathrm{P} 1$ had the highest priority of 22.86, followed by P4, P6, P2, P5, and P3 with the scores of 19.23, 17.47, 15.01, 13.42, and 12.01, sequentially.

\section{B. Project manager-to-project matching}

This step contains two parts: 1) quantifying the coefficients of effectiveness in managing discontinuity of project managers in projects and 2) calculating the matching score between projects and project managers. Appendix A provides details of the quantification procedures.

Exhibit 9 shows the coefficients of effectiveness in managing discontinuity of project managers in projects, $\alpha_{i j k}$ gathered using a questionnaire. These coefficients are especially necessary in the case of reassignment since they reflect how well project managers manage discontinuity in these projects. For example, the value 0.7 of $\alpha_{214}$ shows 70 percents effectiveness of PM B in managing the discontinuity of project 1 with respect to Goal 4 . Since

Project Manager A, B, C, D, and E were the original project managers of Project 1, 2, 3, 4, and 5 respectively, their coefficients of effectiveness are equal to one for those projects. For P6 (a new project), $\alpha_{i 6 k}$ is equal to one for every project manager and every goal.

\section{Insert Exhibit 9 around here}

Quantifying the matching score between projects and project managers required two steps. First, we asked the director of project management group to develop a list of project 
managers' competencies that should be considered in the assignment process (our list of competencies was provided as a guideline). Second, we asked the director to identify the importance score of each competency to each project by using a pairwise comparison method (a comparison instrument was provided). In this particular assignment, the decision maker identified similar weights of competencies to Project 2, 3, 4, 5, and 6 since they are platform projects (see Exhibit 10).

\section{Insert Exhibit 10 around here}

Exhibit 11 illustrates the matrices of required and available competencies after being rated by using 1-5 Anchor scales - (anchor statements were developed and provided). Exhibit 11 also shows the matching scores between projects and project managers $\left(W_{i j}\right)$ after following the steps discussed in Appendix A. Based on the matching scores, PM B, PM C, and PM D have a high correspondence level with every project (their competencies match with the project requirements). PM A and PM E have a lower correspondence level with projects than PM B, PM C, and PM D but a higher correspondence level than PM F. Since PM C had the highest competency score (5) for every competency, his correspondence level, $W_{3 j}$, is the maximum value (100.00).

\section{Insert Exhibit 11 around here}

\section{Recognition of limitations}

In this particular assignment, the director placed special emphasis on the resource availability of project managers and special requirements (Exhibit 12). He argued that the other 
constraints, e.g. phase-mix, type-mix, and maximum number of projects, which were rather simple to formulate, were already reflected in the resource availability constraints (projects in different phases and types require different amounts of time from a project manager).

Exhibit 12 illustrates the equations and data representing the resource availability and special assignment constraints. For the resource availability constraints, the values of $D_{i j}$ (time demand of project $j$ from project manager $i$ ) are the future demands of projects (e.g. next 12 weeks). These demands vary depending on the experience level of project managers. The switchover-time loss $\left(S_{i}\right)$ is captured by using Equation 2.2-2.7. The resource availability of a project manager $\left(A_{i}\right)$ is the future time availability of a project manager (the next 12 weeks). In terms of special assignment constraints, we formulated the equations to represent the request of the director that P1 had special requirements, and only PM A, PM C, and PM D could respond to them.

\section{Insert Exhibit 12 around here}

\section{An optimization model for project manager assignments}

The objective function and the mathematical constraints of an optimization model for project manager assignments are summarized in Exhibit 13. In addition to the constraints illustrated in Exhibit 12, some technical constraints were added. Those constraint are 1) each project must be assigned and it must be assigned to only one project manager (project assignment constraints), 2) every project manager must be assigned one project (project manager assignment constraints), 3 ) declarations of binary decision variables $\left(X_{i j}, \gamma_{i j}\right.$, and $\left.Z_{i j}\right)$. 
The results after model execution are also in Exhibit 13. The value of the objective function was $8,786.86$. The model suggested some changes in project managers of some existing projects. P1 (the highest priority project) was assigned to PM C (the most experienced project manager) instead of its original PM A. P6 (the second most important project) was assigned to PM E, who had more experience than PM F (originally available). This shows that the model is capable of performing reassignment. The total project time demand and the project managers' resource availability after assignments are also shown in Exhibit 13. These results reflect the objective of the model "the strategically important projects should be assigned to the skilled project managers (the parameters in the objective function) with respect to the organizational/personal limitations (the parameters in the mathematical constraints)."

\section{Insert Exhibit 13 around here}

In comparison, if the director of project management group decided not to change the original assignment and assigned P6 to PM F, this decision yielded the objective function value of $8,348.30$. In other words, the reassignment results from the model produce approximately $5 \%$ improvement in the objective function value. From the resource availability after assignments standpoint, project managers A to F would have $96,180,152,200,163$, and 144 hours available over the 12-week-horizon respectively. Comparing these values to the results from reassignments- $164,180,96,200,215$, and 84 hours available over the 12-week-horizon--PM $\mathrm{C}$, who is very experienced, had more workload while the other project managers, e.g. PM A and E had more availability. 
In fact, the results from the model are no more than a guideline for the director of the project management group. After presenting these results to him, the director found the assignment decisions reasonable. He stated that, "The model correctly prioritizes the individual projects in line with our business needs... The model correctly matches the skill sets and experience levels of the project managers with the project requirements." He also mentioned that the assignment decisions from the model are similar to what he had in mind and commented that "Having a tool such as this would give me an excellent starting position for resource assignments." He also stated that this model can save a large amount of time in resource allocation and planning if the organization is sufficiently large. However, he said, "Project assignments will almost always require the final decision to be completed by management." The reason is that there may be some external factors that should also be considered. However, it may not be appropriate to incorporate these factors into the model since they would make the model overly complex.

\section{CONTRIBUTIONS \& MANAGERIAL IMPLICATIONS}

\section{A. Contributions}

This study, which is a combination of a descriptive and prescriptive study, contributes to the management literature by investigating the process of project assignments in multiple-project environments when project managers manage multiple concurrent projects, which has been long ignored. In particular, to our knowledge, we are among the first to empirically examine the multifaceted assignment criteria that span from the organizational strategic factors, to the project requirements, to the project manager's competencies, and to the organizational/personal limitations. This study also examines mediating steps through which the assignment criteria 
affect project manager assignments, helping researchers to better understand how assignments occur in high-tech companies. In addition, this study adds to the previous work on the theory of project assignments by providing a theoretical framework with a comprehensive and systematic decision-making model based on previously mentioned assignment criteria and mediating steps in the assignment process. This theoretical framework can be integrated into a broader enterprise project management system and can stimulate the future research in project manager selection.

\section{B. The use of the assignment model}

In terms of its implications, the project assignment model can be used in several situations. It can be used in the assignment of project managers who lead one project or multiple, simultaneous projects. The model can help assign new projects as well as reassign existing projects to project managers. In fact, its reassignment capability makes the model unique and creates the possibility using it at any point in time (not only when having all new projects and all new candidate project managers).

\section{How to develop the assignment model in practice}

To develop the assignment model in practice, we propose that an organization use a contingency approach, which can be seen from the example discussed in this paper. The process starts with a) selecting appropriate criteria, b) gathering the information to quantify the value of parameters, and c) developing an integer programming model.

a) Selecting appropriate criteria: Four groups of criteria are proposed in the study as a platform for decision maker develops specific assignment criteria within these groups as needed for their particular company. The four groups of criteria are the organization's 
strategic elements, the project requirements, the competencies of the project managers, and the organizational/personal limitations. Please refer to [42] for a list of criteria, researched under the environments of new product development in high-tech industries, as guidelines.

b) Gathering the information to quantify the values of parameters: After the criteria are selected, the information regarding the projects to be assigned and the candidate project managers should be gathered. This includes project type, project phase, level of requirements, project time demand, competency level of project managers, and resource availability of project managers, etc. Next is a quantification step, including quantifying the values of the parameters in the objective function and the mathematical constraints as mediating steps in project manager assignments. The Analytic Hierarchy Process together with the criteria in a group of organizational strategic elements can be used to identify the parameters relating to project priority $\left(G_{k}\right.$ and $\left.V_{j k}\right)$. The discontinuity in project management parameters $\left(\alpha_{i j k}\right)$ can be subjectively rated for each project and each project manager. The use of the competency matrices and criteria in the groups of project requirements and competencies of project managers help quantify the project manager-toproject matching scores $\left(W_{i j}\right)$. Please refer to Appendix A for our proposed techniques for quantifying these parameters. In terms of mathematical constraints, as mentioned earlier, the information regarding the limitations, e.g. project time demand and the time availability of project managers can be estimated based on the types and phases of projects, and levels of project managers instead of estimating them individually for each project and each project manager. The use of systematic questionnaires can help alleviate the challenges in the data gathering and quantification process. 
c) Developing an integer programming model: An integer programming model for project assignments can be developed using any commercially available software platform. The input data of the model is the values resulting from the quantification of the parameters, discussed earlier. The results from model execution are the assignment guidelines for management to use in making assignment decisions. In addition, sensitivity analysis can be performed to understand the impact of changes of the input values on the results.

In some cases, the data gathering and quantification process can be cumbersome. However, having a systematic approach to do so and using a software program that enables data gathering, quantification of parameters, and development of the integer programming model may help. Note that the project assignment model developed in this research demonstrates its application in the environment of product development projects. In order to apply the model to different environments, the structure and concepts of the model, including the process of model development, may be utilized. Some assignment criteria may have to be revised.

\section{CONCLUSION AND FUtURE RESEARCH}

As a result of this research, we present a theoretical framework for project manager assignments that includes multifaceted assignment criteria and process, as well as an integerprogramming model as a systematic methodology. This theoretical framework can be used as an extension of the project selection process.

While other researchers propose project assignment methodologies based on the correspondence level between project requirements and the competencies of project managers, 
this research proposes two additional steps in the process: project prioritization and recognition of limitations, which are valuable extensions of the work of other researchers. With these additional steps, the model assists management in assigning projects to project managers by considering the organizational strategic elements, project requirements, competencies of project managers, and organizational/personal limitations. These considerations guide project manager assignments to enhance the performance of projects and the organization, including the performance of project managers in leading projects to their success.

Despite the contribution of this model, several opportunities exist for its future improvement. Firstly, the objective function and some mathematical constraints of the optimization model may be formulated as a function of time. This will definitely increase the complexity of the model; however, it will make the model more dynamic, and project assignment decisions will be made by considering, for example, the balanced workload of project managers over time. Secondly, the objective function may include some additional parameters representing the synergy effect from assigning projects with interdependencies and interactions to the same project manager. Thirdly, the equations of the switchover-time loss, parts of the resource availability constraints, can be modified to capture the number of projects per project manager at a given time, leading to more accuracy in the estimation of switchover-time loss. Finally, the benefit of multiple project management in terms of organization efficiency and knowledge transfer, which can compensate for a multitasking penalty, can be further investigated. 


\section{REFERENCE}

[1] A. B. Badiru, Project Management in Manufacturing and High-Technology Operations. New York: John Wiley \& Sons, 1996.

[2] K. Forsberg, H. Mooz, and H. Cotterman, Visualizing Project Management, Second ed. New York: John Wiley \& Sons, Inc., 2000.

[3] J. K. Pinto and D. P. Slevin, "Critical success factors across the project life cycle," Project Management Journal, vol. 19, pp. 67-74, 1988.

[4] J. K. Pinto and D. P. Slevin, "Critical success factors in R\&D projects," Research Technology Management, vol. 32, pp. 31-35, 1989.

[5] S. L. Brown and K. M. Eisenhardt, "Product development: Past research, present findings, and future directions," Academy of Management Journal, vol. 20, pp. 343-378, 1995.

[6] J. R. Adams, S. E. Barndt, and M. D. Martin, Managing By Project Management. Dayton, Ohio: Universal Technology Corporation, 1979.

[7] J. Hauschildt, G. Keim, and J. W. Medof, "Realistic criteria for project manager selection and development," Project Management Journal, vol. 31, pp. 23-32, 2000.

[8] S. A. Mian and C. X. Dai, "Decision-making over the project life cycle: An analytical hierarchy approach," Project Management Journal, vol. 30, pp. 40-52, 1999.

[9] H. K. Bowen, K. B. Clark, C. A. Holloway, and S. C. Wheelwright, "Development projects: The engine of renewal," Harvard Business Review, vol. 72, pp. 110-120, 1994.

[10] J. S. Pennypacker and L. D. Dye, "Project portfolio management and managing multiple projects: Two sides of the same coin?," in Managing Multiple Projects, J. S. Pennypacker and L. D. Dye, Eds. New York: Marcel Dekker Inc., 2002, pp. 1-10.

[11] R. G. Cooper, S. J. Edgett, and E. J. Kleinschmidt, Portfolio Management for New Products. Reading, M.A.: Perseus Books, 1998.

[12] L. R. Ireland, "Managing multiple project in the twenty-first century," in Managing multiple projects, J. S. Pennypacker and L. D. Dye, Eds. New York: Marcel Dekker Inc., 1997, pp. 21-34.

[13] S. E. Fricke and A. J. Shenhar, "Managing multiple engineering projects in a manufacturing support environment," IEEE Transactions on Engineering Management, vol. 47, pp. 258-268, 2000.

[14] A. J. Kuprenas, C.-L. Jung, S. A. Fakhouri, and G. W. Jreij, "Project manager workloadassessment of values and influences," Project Management Journal, vol. 31, pp. 44-51, 2000.

[15] D. Milosevic and P. Patanakul, "Secrets of successful multiproject managers," Proceedings of Project Management Institute' 2002 Annual Seminars and Symposium, San Antonio, Texas, 2002.

[16] P. O. Gaddis, "The project manager," in Managing Projects and Programs, N. R. Augustine, Ed. Boston: Harvard Business School Press, 1959, pp. 145-162.

[17] R. D. Archibald, Managing High-Technology Programs and Projects. New York:: Wiley, 1975.

[18] N. Pettersen, "Selecting project Managers: An integrated list of predictors," Project Management Journal, vol. 22, pp. 21-26, 1991.

[19] H. J. Thamhain, "Developing project management skills," Project Management Journal, vol. 22, pp. 39-45, 1991.

[20] J. D. Frame, Building Project Management Competence. San Francisco: Jossey-Bass Publishers, 1999.

[21] R. J. Thieme, M. Song, and G.-C. Shin, "Project management characteristics and new product survival," The Journal of Product Innovation Management, vol. 20, pp. 104, 2003.

[22] R. Suikki, R. Tromstedt, and H. Haapasalo, "Project management competence development framework in turbulent business environment," Technovation, vol. 26, pp. 723, 2006.

[23] H. Birnberg, "How many project managers do you need?," Civil Engineering News, pp. 34, 1997.

[24] W. R. Duncan, "The project manager," PM Network, vol. 13, pp. 19, 1999.

[25] A. J. Shenhar, "One size does not fit all projects: Exploring classical contingency domains," Management Science, vol. 47, pp. 394-414, 2001. 
[26] L. Simon, "Managing creative projects: An empirical synthesis of activities," International Journal of Project Management, vol. 24, pp. 116, 2006.

[27] R. L. Katz, "Skills of an effective administrator," Harvard Business Review, vol. 33, pp. 33-42, 1955.

[28] A. J. Shenhar and H. J. Thamhain, "A new mixture of management skills: Meeting the hightechnology managerial challenges," Human Systems Management, vol. 13, pp. 27-40, 1994.

[29] S. M. George, "Top priority management concerns about new product development," The Academy of Management Executive, vol. 13, pp. 77-84, 1999.

[30] K. M. Eisenhardt and S. L. Brown, "Time pacing: Competing in markets that won't stand still," Harvard Business Review, vol. 76, pp. 59-69, 1998.

[31] P. S. Adler, A. Mandelbaum, V. Nguyen, and S. Elizabeth, "Getting the most out of your product development process," Harvard Business Review, vol. 74, pp. 134-146, 1996.

[32] M. H. Meyer and J. M. Utterback, "The product family and the dynamics of core capability," Sloan Management Review, vol. 34, pp. 29-47, 1993.

[33] M. H. Meyer and R. Seliger, "Product platforms in software development," Sloan Management Review, vol. 40, pp. 61-74, 1998.

[34] M. V. Tatikonda, "An empirical study of platform and derivative product development projects," Journal of Product Innovation Management, vol. 16, pp. 3-26, 1999.

[35] R. F. Maruca, "Mapping the world of customer satisfaction," Harvard Business Review, vol. 78, pp. 30, 2000.

[36] M. W. Dickinson, A. C. Thornton, and S. Graves, "Technology portfolio management: Optimizing interdependent projects over multiple time periods," IEEE Transactions on Engineering Management, vol. 48, pp. 518, 2001.

[37] A. Platje and H. Seidel, "Breakthrough in multiproject management: How to escape the vicious circle of planning and control," International Journal of Project Management, vol. 11, pp. 209213, 1993.

[38] A. Platje, H. Seidel, and S. Wadman, "Project and portfolio planning cycle: project-based management for multiproject challenge," International Journal of Project Management, vol. 12, pp. 100-106, 1994.

[39] K. M. Eisenhardt, "Building theories from case study research," Academy of Management Review, vol. 14, pp. 532-550, 1989.

[40] R. Yin, Case study research: Design and methods, vol. 5, Second ed. CA: Sage Publications, 1984.

[41] H. A. Linstone and M. Turoff, The Delphi Method. Reading, Massachusetts: Addison-Wesley Publishing Company, 1975.

[42] D. Milosevic and P. Patanakul, "A model for assigning projects to project managers in multiple project management environments," in Innovations-Project management research 2004", D. P. Slevin, J. K. Pinto, and D. I. Cleland, Eds. Newtown Square, PA: Project Management Institute, 2004.

[43] P. Patanakul and D. Milosevic, "Assigning new product projects to multiple-project managers: What market leaders do," Journal of High Technology Management Research, vol. 17, 2006.

[44] M. R. Garey and D. S. Johnson, Computers and intractability. New York: WH Freeman \& Co, 1979.

[45] B. V. Dean, D. R. Denzler, and J. J. Watkins, "Multiproject staff scheduling with variable resource constraints," IEEE Transactions on Engineering Management, vol. 39, pp. 59-72, 1992.

[46] K. A. Dowsland and J. M. Thompson, "Solving a nurse scheduling problem with knapsaks, networks, and tabu search," Journal of the Operational Research Society, vol. 51, pp. 825-833, 2000.

[47] A. A. Zoltners and P. Sinha, "Integer programming models for sales resource allocation," Management Science, vol. 26, pp. 242, 1980. 
[48] S. C. Graves and B. W. Lamar, "An integer programming procedure for assembly system design problem," Operations Research, vol. 31, pp. 522-545, 1983.

[49] A. Bolat, "Models and a genetic algorithm for static aircraft-gate assignment problem," Journal of the Operational Research Society, vol. 52, pp. 1107-1120, 2001.

[50] P. Patanakul and D. Milosevic, "Multiple-project manager: What competencies do you need?," Project perspectives, vol. XXVII, pp. 28-33, 2005.

[51] T. L. Saaty, The Analtytic Hierarchy Process. New York: McGraw-Hill, 1980.

[52] D. F. Kocaoglu, "A participative approach to program evaluation," IEEE Transactions on Engineering Management, vol. EM30, pp. 112-118, 1983.

[53] J. S. Rubinstein, D. E. Meyer, and J. E. Evans, "Executive control of cognitive process in task switching," Journal of Experimental Psychology: Human Perception and Performance, vol. 27, pp. 763-797, 2001.

[54] J. R. Harris and J. C. McKay, "Optimizing product development through pipeline management," in The PDMA Handbook of New Product Development, M. D. Rosenau, Ed. New York: Wiley, 1996.

[55] KapurInternational, "Project Management Seminar Handbook," San Ramon, CA: Center for Project Management, 1993. 
Appendix A: The quantification procedures for the parameters of the objective function

\section{The quantification of $G_{k}$ and $V_{j k}$}

For every candidate project, the values of $G_{k}$ and $V_{j k}$ can be quantified by using the decision hierarchy. To do so, the hierarchy may be constructed with three hierarchical levels. The top level of the hierarchy is an organizational mission. The organizational goals are placed on the second level while the third level consists of projects to be assigned. To quantify a decision hierarchy, a pairwise comparison method either the 1-9 scale of Satty [51] or a constant-sum method of Kocaoglu [52] can be used. For the constant-sum method, the process starts with pairwise comparisons of organizational goals to identify their relative contribution to the organizational mission $\left(G_{k}\right)$, resulting in a mission-goal matrix ( $\mathrm{MG}_{\text {mission }}$ $\mathrm{x}$ goal). The second step is pairwise comparisons of projects to identify their relative contribution to each organizational goal $\left(V_{j k}\right)$, producing a goal-project matrix (GP goal $\mathrm{xproj}_{\text {pro }}$. If the matrix multiplication, (MG $\mathrm{X}$ GP), as proposed by Kocaoglu [52], is performed, the results will be the relative contribution of each project to the organizational mission $\left(V_{j}\right)$.

\section{The quantification of $\alpha_{i j k}$}

The value of $\alpha_{i j k}$ represents the coefficient of effectiveness of project manager $i$ in managing project $j$ 's contribution to goal $k$ when there is a discontinuity in the management of project $j$. As already mentioned, $\alpha_{i j k}$ is equal to 1 for i) every project manager for new projects and ii) the original project managers of the existing projects (candidates for reassignment) since discontinuity in management does not occur in those cases. In other cases, the magnitude of $\alpha_{i j k}$ depends on the ability of project managers in managing discontinuity in those projects' contribution to goal $k$, and the value of $\alpha_{i j k}$ is between 0 and 1. The value of 0 means complete failure in discontinuity management. On the other hand, the value of 1 means full effectiveness as if no discontinuity has occurred. While the determination of these coefficients with respect to each goal may be time consuming; it helps a decision maker be more focused during the quantification process - looking at a single goal at a time.

For each existing project $j, \alpha_{i j k}$ has to be quantified for each project manager and each goal. The quantification process of $\alpha_{i j k}$ is very subjective. Several factors influence the value of $\alpha_{i j k}$, for example, the current phase of projects, project characteristics, or some impact on project deliverables, e.g. delay, budget overrun, or quality problems because of discontinuity in management. A decision maker has to take these factors into consideration when quantifying $\alpha_{i j k}$. To quantify $\alpha_{i j k}$, the question that should be asked is: 
"If there is a discontinuity in the management of project $\boldsymbol{j}$ (project's name) due to its assignment to project manager $\boldsymbol{i}$ (project manager's name), who is not its current project manager, what is your judgment about the effectiveness of project manager $\boldsymbol{i}$ (project manager's name) in managing the discontinuity with respect to achieving goal $\boldsymbol{k}$. Please use a value between 0 and $100 \%$, with $0 \%$ representing a complete failure and $100 \%$ representing full effectiveness as if no discontinuity has occurred."

The values of $\alpha_{i j k}$ can be presented in a table format as in Exhibit A1.

\section{Insert Exhibit A1 around here}

\section{The quantification of $W_{i j}$}

The correspondence levels between projects and project managers $\left(W_{i j}\right)$ are the project managerto-project matching score based on project requirements and competencies of project managers. $W_{i j}$ is quantified by using the matrix of required competencies and the matrix of available competencies (see Exhibit A2 and A3 for examples).

The matrix of required competencies is used to identify the level of competencies of project managers that were required for managing projects. It represents the use of criteria in the group of project requirements in project assignments. However, those project requirements are not directly presented in this matrix but rather are in the form of the competencies that projects require from project managers. In this matrix, each row represents each project managers' competency that projects require, and each column represents each candidate project to be assigned (Exhibit A2). The matrix of available competencies is used to evaluate the level of competencies that candidate project managers possess. Those competencies are in the rows of the matrix, while the names of candidate project managers are in the column (Exhibit A3). In project assignments, these matrices are used to find proper matches between projects and project managers. The quantification procedure is as follows:

\section{Insert Exhibit A2 around here}

\section{Insert Exhibit A3 around here}

$>$ Both the matrix of required competencies and the matrix of available competencies can be quantified by using 1-5 Anchor scales to identify, for each competency, the level each project needs and the level that each project manager can provide (1=very low, 5=very high), as shown in Exhibit A4. We found that the use of Anchor scales (scales with statements) makes the rating simpler. 
To examine match competency between projects and project managers, we compare the level of each competency that project manager $i$ can provide with the level that the project $j$ needs. If the difference is zero or a positive value, we consider it as a good match competency. If the difference is a negative value, we considered it as a no match competency. Then, for a good match competency, we code it as " 1 " and for a no match competency, we code it as " 0 ." However, if it is acceptable in the organization that a project manager has one level of competency less than that which the project requires (the difference is " -1 "), we propose a coding of " 0.5 " or a somewhat match competency - a common practice to help a project manager improve skills. This procedure repeats for every project manager. For project $j$, the results from the coding create the coding matrix. [This coding step is important. It helps eliminate the offsetting of a very strong match in one competency (the difference is very positive) over the complete lack of match in another competency (the difference is very negative) since the final matching score will be calculated in part by the summation of the matching score from each competency, discussed next].

$>$ In the coding matrix, for each competency, the coding score of project manager $i$ is multiplied with the level of importance (weight) of that competency to the project, resulting in the weighted score of the project manager with respect to each competency. The weight of each competency can be quantified from the pairwise comparisons among the competencies. However, instead of quantifying weights of competencies for each project individually, we propose quantifying them by type of project such as breakthrough, platform, and derivative products. If project A and B are the same type, the same weights of competencies are implemented for both projects.

$>$ The project manager-to-project matching score or the correspondence level $\left(W_{i j}\right)$ of project manager $i$ to project $j$ is the summation of his weighted scores from all competencies. The higher the value, the better is the match between project $j$ and project manager $i$.

This calculation is repeated for every project.

\section{Insert Exhibit A4 around here}




\begin{tabular}{|c|c|c|}
\hline $\begin{array}{l}\text { Researched/ } \\
\text { Not Researched }\end{array}$ & $\begin{array}{c}\text { Literature Stream: } \\
\text { Criteria for Assigning Projects to Project } \\
\text { Managers }\end{array}$ & $\begin{array}{c}\text { Literature Stream: } \\
\text { Methodologies for Assigning Projects to Project } \\
\text { Managers }\end{array}$ \\
\hline Researched & $\begin{array}{l}>\text { Competencies of project managers: e.g., } \\
{[16-22]} \\
>\text { Project requirements: e.g., }[23-25]\end{array}$ & $\begin{array}{l}>\text { Assignment based on matching project characteristics } \\
\text { and the capabilities of project managers: e.g., [6] } \\
\text { Assignment based on comparing relative skills of } \\
\text { project managers: e.g., [8] } \\
>\text { Assignment based on matching types of projects and } \\
\text { types of project managers: e.g., [7] }\end{array}$ \\
\hline $\begin{array}{l}\text { Not Researched } \\
\text { (literature gaps) }\end{array}$ & $\begin{array}{l}>\text { Strategic elements of the organization as } \\
\text { criteria } \\
>\text { Organizational limitations as criteria } \\
>\text { A comprehensive list of criteria }\end{array}$ & $\begin{array}{l}\text { Strategic elements of the organization as part of the } \\
\text { process } \\
>\text { Organizational limitations as part of the process } \\
>\text { Methodology based on a comprehensive list of } \\
\text { criteria }\end{array}$ \\
\hline
\end{tabular}

\section{Exhibit 1: Summary of the literature review}




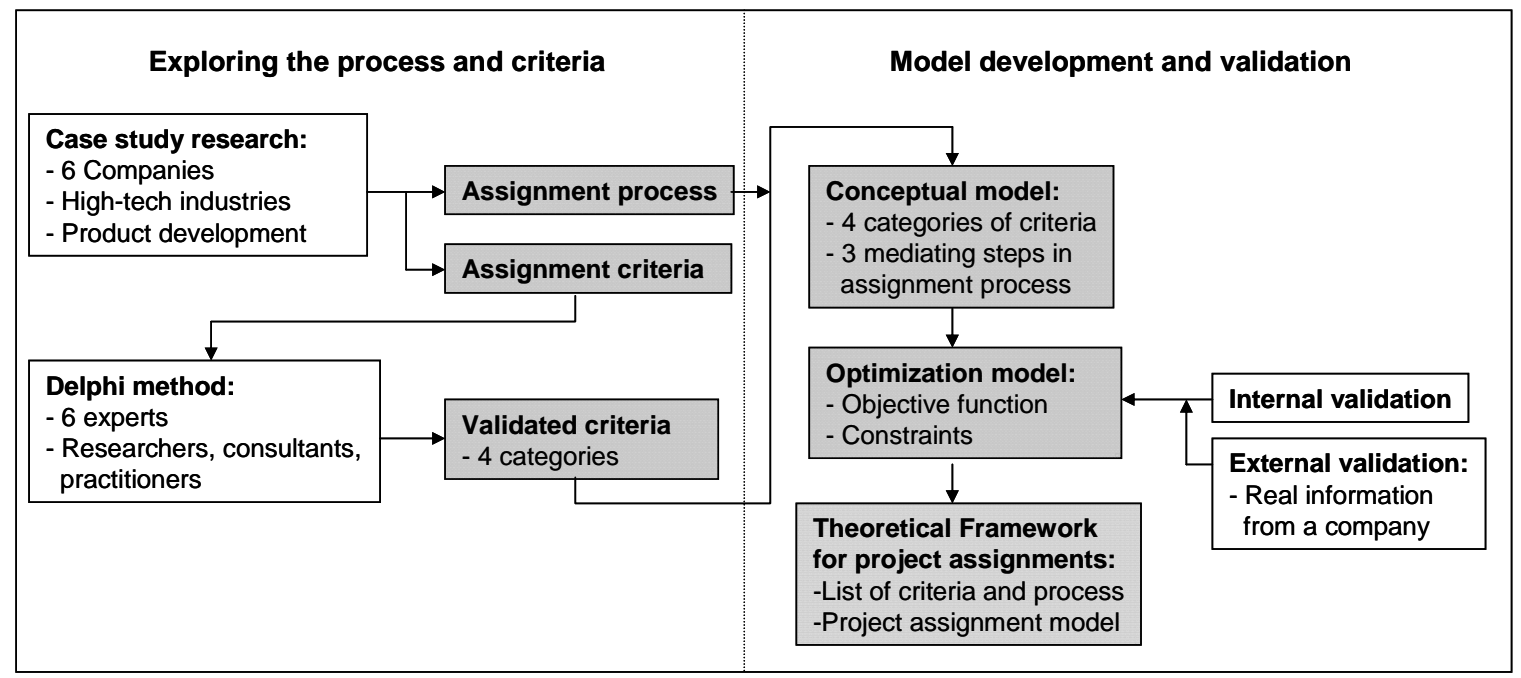

Exhibit 2: Research process 


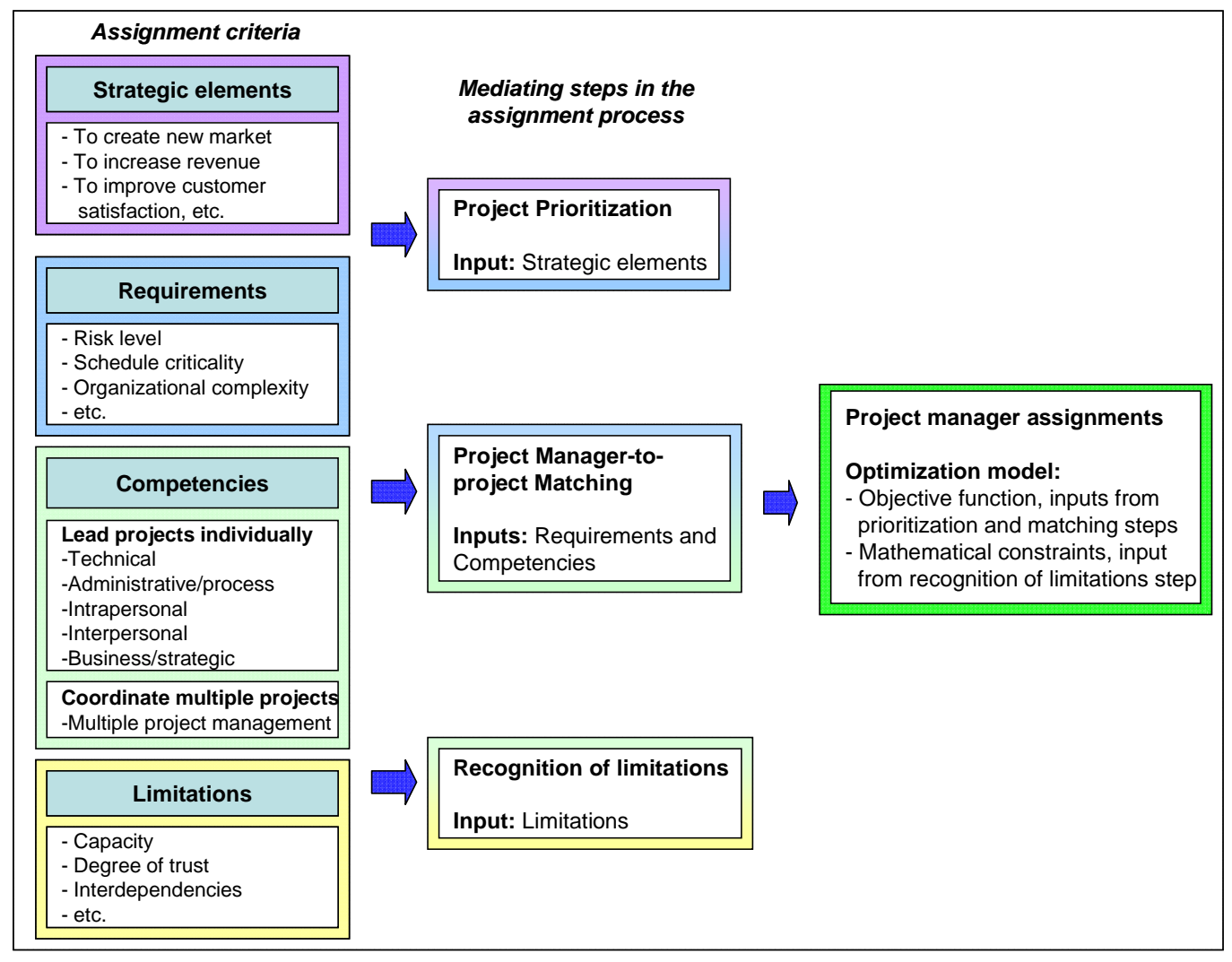

Exhibit 3: A theoretical framework for project manager assignments 


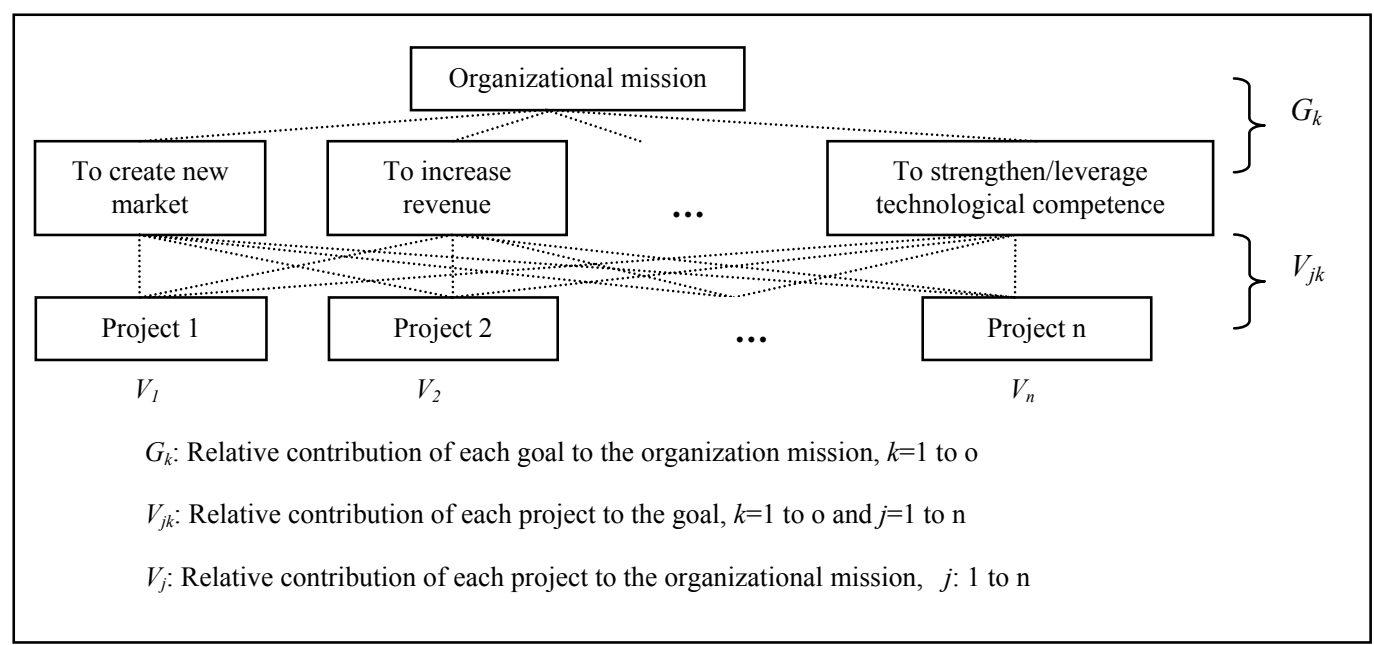

Exhibit 4: The decision hierarchy for project prioritization 


\begin{tabular}{c|c}
\hline Number of projects & Switchover-time loss (person hours per week) \\
\hline $\mathbf{1}$ & 0 \\
$\mathbf{2}$ & 6 \\
$\mathbf{3}$ & $7.5^{*}$ \\
$\mathbf{4}$ & 9 \\
\hline
\end{tabular}

*Interpolated with an assumption of linearity

Exhibit 5: Switchover-time loss per number of projects 


\begin{tabular}{|c|c|c|c|c|c|c|}
\hline & P1 & $\mathbf{P 2}$ & P3 & P 4 & P5 & P6 \\
\hline Project type & Breakthrough & Platform & Platform & Platform & Platform & Platform \\
\hline $\begin{array}{l}\text { Requirements* } \\
\text { Risk level }\end{array}$ & High & High & Very low & High & Medium & High \\
\hline Technical novelty & Very high & High & High & Very high & Medium & High \\
\hline $\begin{array}{l}\text { Organizational } \\
\text { complexity }\end{array}$ & High & Very high & Very high & Very high & Medium & High \\
\hline Task complexity & High & Medium & Medium & High & Medium & High \\
\hline $\begin{array}{l}\text { Schedule } \\
\text { criticality }\end{array}$ & Very high & High & High & High & High & High \\
\hline $\begin{array}{l}\text { Quality } \\
\text { requirements }\end{array}$ & Very high & High & High & High & High & High \\
\hline Team dispersion & Co-located & Distributed & Distributed & Distributed & Distributed & Distributed \\
\hline Project size $(\$)$ & $2,000,000$ & $2,000,000$ & $6,000,000$ & $1,000,000$ & $1,000,000$ & $2,000,000$ \\
\hline $\begin{array}{l}\text { Total project } \\
\text { duration (Weeks) }\end{array}$ & 104 & 65 & 78 & 65 & 35 & $70-104$ \\
\hline Existing vs. new & Existing & Existing & Existing & Existing & Existing & New \\
\hline Current phase $^{\dagger}$ & Exec. & Exec. & Exec. & Conc. & Exec. & - \\
\hline $\begin{array}{l}\text { Duration left } \\
\text { (Weeks/phase }^{\dagger} \text { ) }\end{array}$ & $\begin{array}{l}\text { 40/Exec. } \\
\text { 4/Term. }\end{array}$ & $\begin{array}{l}\text { 20/Exec. } \\
\text { 4/Term. }\end{array}$ & $\begin{array}{l}\text { 8/Exec. } \\
\text { 4/Term. }\end{array}$ & $\begin{array}{l}\text { 10/Conc. } \\
\text { 32/Exec. } \\
\text { 4/Term. }\end{array}$ & $\begin{array}{l}\text { 8/Exec. } \\
\text { 4/Term. }\end{array}$ & $\begin{array}{l}\text { 12+/Conc. } \\
\text { 48+/Exec. } \\
\text { 4+/Term. }\end{array}$ \\
\hline Current PM & $\mathrm{A}$ & $\mathrm{B}$ & $\mathrm{C}$ & $\mathrm{D}$ & $E$ & - \\
\hline
\end{tabular}

*Scales: Very high, high, medium, low, and very low, ${ }^{\dagger}$ Conc: Conceptual \& Planning, Exec: Execution, Term: Termination

Exhibit 6: Projects to be assigned 


\begin{tabular}{|c|c|c|c|c|c|c|}
\hline & PM A & PM B & PM C & PM D & PM E & PM F \\
\hline Level $^{\dagger}$ & 2 & 3 & 3 & 3 & 2 & 1 \\
\hline \multicolumn{7}{|l|}{ Current projects } \\
\hline $\begin{array}{l}\text { - Name } \\
\text { - Type } \\
\text { - Duration left } \\
\text { (weeks/phase**) }\end{array}$ & $\begin{array}{c}\text { Project } 1 \\
\text { Breakthrough } \\
\text { 40/Exec. } \\
\text { 4/Term. }\end{array}$ & $\begin{array}{l}\text { Project } 2 \\
\text { Platform } \\
\text { 20/Exec. } \\
\text { 4/Term. }\end{array}$ & $\begin{array}{l}\text { Project } 3 \\
\text { Platform } \\
\text { 8/Exec. } \\
\text { 4/Term. }\end{array}$ & $\begin{array}{l}\text { Project } 4 \\
\text { Platform } \\
\text { 10/Conc. } \\
\text { 32/Exec. } \\
\text { 4/Term. }\end{array}$ & $\begin{array}{l}\text { Project } 5 \\
\text { Platform } \\
\text { 8/Exec. } \\
\text { 4/Term. }\end{array}$ & $\begin{array}{c}\text { Project } 7 \\
\text { Derivative } \\
\text { 8/Exec. } \\
\text { 4/Term. }\end{array}$ \\
\hline $\begin{array}{l}\text { - Name } \\
\text { - Type } \\
\text { - Duration left } \\
\text { (weeks/phase**) }\end{array}$ & $\begin{array}{c}\text { Project } 8 \\
\text { Breakthrough } \\
\text { 20/Conc. } \\
\text { 80/Exec. } \\
\text { 4/Term. }\end{array}$ & $\begin{array}{c}\text { Project } 9 \\
\text { Derivative } \\
\text { 20/Exec. } \\
\text { 4/Term. }\end{array}$ & $\begin{array}{c}\text { Project 10 } \\
\text { Breakthrough } \\
\text { 24/Exec. } \\
\text { 4/Term. }\end{array}$ & $\begin{array}{c}\text { Project } 11 \\
\text { Breakthrough } \\
\text { 18/Exec. } \\
\text { 4/Term. }\end{array}$ & $\begin{array}{l}\text { Project } 12 \\
\text { Platform } \\
\text { 5/Conc. } \\
\text { 48/Exec. } \\
\text { 4/Term. }\end{array}$ & - \\
\hline $\begin{array}{l}\text { Existing } \\
\text { workload* }\end{array}$ & 480 & 396 & 424 & 376 & 413 & 216 \\
\hline $\begin{array}{l}\text { Name of project } \\
\text { to be reassigned }\end{array}$ & Project 1 & Project 2 & Project 3 & Project 4 & Project 5 & \\
\hline Project demand* & 276 & 216 & 184 & 136 & 208 & \\
\hline $\begin{array}{l}\text { Existing } \\
\text { workload* } \\
\text { after taking off } \\
\text { reassignments }\end{array}$ & 204 & 180 & 240 & 240 & 205 & 216 \\
\hline
\end{tabular}

${ }^{\dagger}$ 1: Junior, 3: Senior, *Unit: Person-hours per planning horizon (12 weeks),

**Conceptual \& Planning: Conc., Execution: Exec., Termination: Term.

Exhibit 7: Candidate project managers 
"Our initiative centered on maintaining customer focus and driving down cost through a restructuring program while we leveraged our core competencies in advanced research and engineering design to develop new markets."

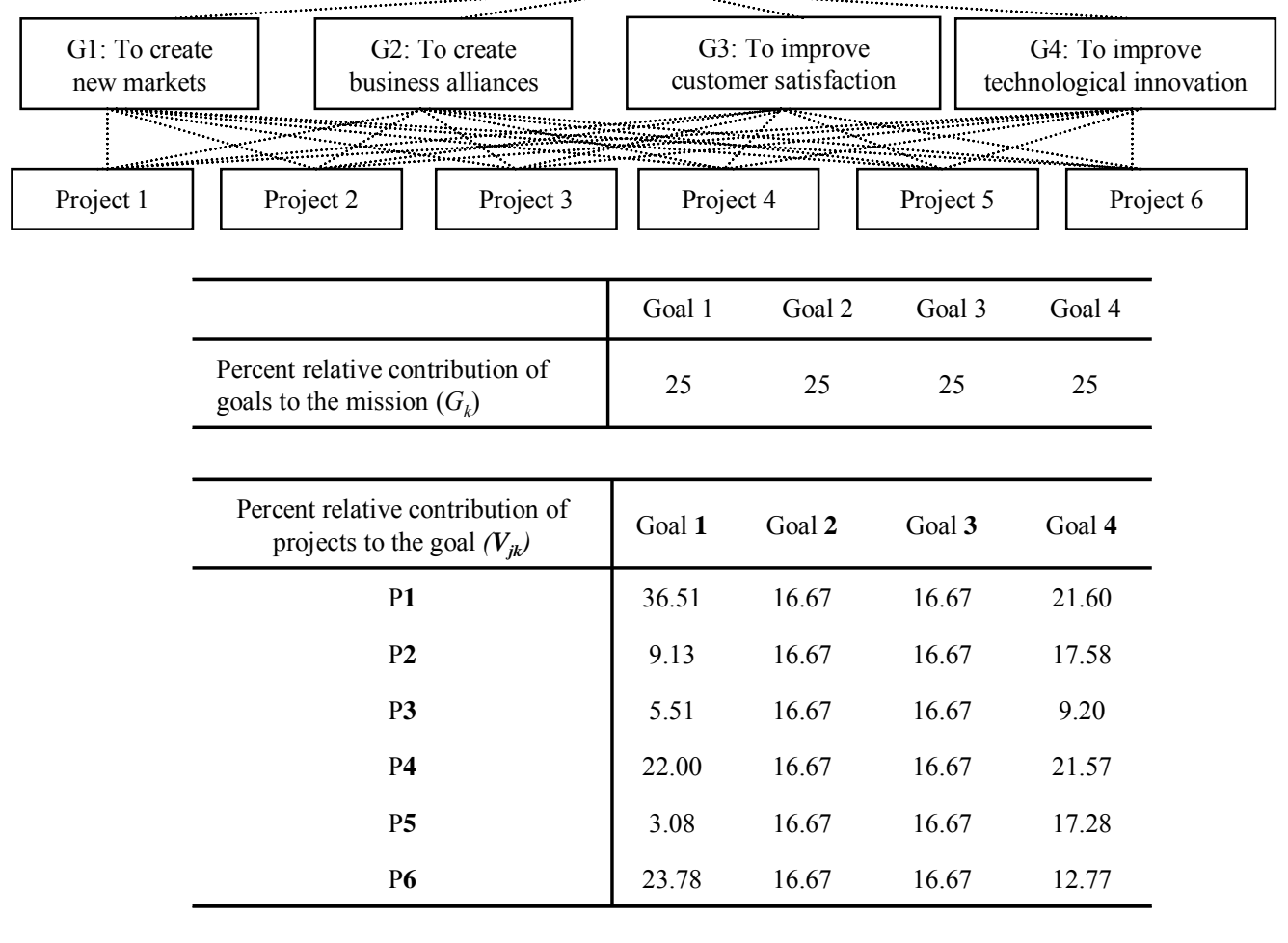

Exhibit 8: A decision hierarchy for project prioritization 


\begin{tabular}{|c|c|c|c|c|c|c|c|c|c|c|c|c|}
\hline \multirow{2}{*}{$\alpha_{i j k}$} & \multicolumn{4}{|c|}{ P1 } & \multicolumn{4}{|c|}{ P2 } & \multicolumn{4}{|c|}{ P3 } \\
\hline & G1 & G2 & G3 & G4 & G1 & G2 & G3 & G4 & G1 & G2 & G3 & G4 \\
\hline PM A & 1 & 1 & 1 & 1 & 1 & 0.9 & 1 & 0.8 & 1 & 0.8 & 0.95 & 1 \\
\hline PM B & 0.9 & 0.9 & 1 & 0.7 & 1 & 1 & 1 & 1 & 1 & 0.8 & 0.95 & 1 \\
\hline PMC & 0.9 & 0.9 & 1 & 0.7 & 1 & 0.9 & 1 & 0.8 & 1 & 1 & 1 & 1 \\
\hline PM D & 0.9 & 0.9 & 1 & 0.7 & 1 & 0.9 & 1 & 0.8 & 1 & 0.8 & 0.95 & 1 \\
\hline PM E & 0.9 & 0.9 & 1 & 0.7 & 1 & 0.9 & 1 & 0.8 & 1 & 0.8 & 0.95 & 1 \\
\hline PM F & 0.9 & 0.9 & 1 & 0.7 & 1 & 0.9 & 1 & 0.8 & 1 & 0.8 & 0.95 & 1 \\
\hline \multirow{2}{*}{$\alpha_{i j k}$} & \multicolumn{4}{|c|}{$\mathrm{P} 4$} & \multicolumn{4}{|c|}{ P5 } & \multicolumn{4}{|c|}{$\mathrm{P} 6$} \\
\hline & G1 & G2 & G3 & G4 & G1 & G2 & G3 & G4 & G1 & G2 & G3 & G4 \\
\hline PM A & 0.6 & 1 & 1 & 0.8 & 1 & 1 & 1 & 1 & 1 & 1 & 1 & 1 \\
\hline PM B & 0.6 & 1 & 1 & 0.8 & 1 & 1 & 1 & 1 & 1 & 1 & 1 & 1 \\
\hline PM C & 0.6 & 1 & 1 & 0.8 & 1 & 1 & 1 & 1 & 1 & 1 & 1 & 1 \\
\hline PM D & 1 & 1 & 1 & 1 & 1 & 1 & 1 & 1 & 1 & 1 & 1 & 1 \\
\hline PM E & 0.6 & 1 & 1 & 0.8 & 1 & 1 & 1 & 1 & 1 & 1 & 1 & 1 \\
\hline PM F & 0.6 & 1 & 1 & 0.8 & 1 & 1 & 1 & 1 & 1 & 1 & 1 & 1 \\
\hline
\end{tabular}

Exhibit 9: The coefficient of effectiveness in discontinuity management of project managers in projects 


\begin{tabular}{|c|c|c|c|c|c|c|c|}
\hline \multicolumn{2}{|c|}{ Competencies } & \multirow{2}{*}{$\begin{array}{c}\mathrm{P} 1 \\
8.4659\end{array}$} & \multirow{2}{*}{$\frac{\mathrm{P} 2}{4.1201}$} & \multirow{2}{*}{$\frac{\text { P3 }}{4.1201}$} & \multirow{2}{*}{$\frac{\mathrm{P} 4}{4.1201}$} & \multirow{2}{*}{$\frac{\text { P5 }}{4.1201}$} & \multirow{2}{*}{$\frac{\text { P6 }}{4.1201}$} \\
\hline Technical & $\begin{array}{l}\text { Knowledge of product } \\
\text { applications }\end{array}$ & & & & & & \\
\hline \multirow{5}{*}{$\begin{array}{l}\text { Administrative/ } \\
\text { process }\end{array}$} & Monitoring/control & 3.9508 & 4.1201 & 4.1201 & 4.1201 & 4.1201 & 4.1201 \\
\hline & Risk management & 11.8523 & 8.4826 & 8.4826 & 8.4826 & 8.4826 & 8.4826 \\
\hline & Planning/scheduling & 2.6338 & 3.3930 & 3.3930 & 3.3930 & 3.3930 & 3.3930 \\
\hline & Resource management & 6.3212 & 6.3014 & 6.3014 & 6.3014 & 6.3014 & 6.3014 \\
\hline & $\begin{array}{l}\text { Company's project } \\
\text { management process }\end{array}$ & 1.3169 & 1.9389 & 1.9389 & 1.9389 & 1.9389 & 1.9389 \\
\hline \multirow{5}{*}{ Intrapersonal } & Responsible & 3.6300 & 2.9561 & 2.9561 & 2.9561 & 2.9561 & 2.9561 \\
\hline & Proactive and ambitious & 3.7752 & 3.4936 & 3.4936 & 3.4936 & 3.4936 & 3.4936 \\
\hline & Mature and self-controlled & 2.9040 & 3.3592 & 3.3592 & 3.3592 & 3.3592 & 3.3592 \\
\hline & Organized and disciplined & 1.5972 & 1.2093 & 1.2093 & 1.2093 & 1.2093 & 1.2093 \\
\hline & Flexible & 1.9820 & 2.4950 & 2.4950 & 2.4950 & 2.4950 & 2.4950 \\
\hline \multirow{6}{*}{ Interpersonal } & Leadership & 8.4659 & 5.7682 & 5.7682 & 5.7682 & 5.7682 & 5.7682 \\
\hline & Communication & 8.4659 & 3.4085 & 3.4085 & 3.4085 & 3.4085 & 3.4085 \\
\hline & Conflict management & 4.4170 & 3.1463 & 3.1463 & 3.1463 & 3.1463 & 3.1463 \\
\hline & Team management & 4.4170 & 4.9816 & 4.9816 & 4.9816 & 4.9816 & 4.9816 \\
\hline & Negotiation & 2.4684 & 2.2843 & 2.2843 & 2.2843 & 2.2843 & 2.2843 \\
\hline & Problem solving & 5.1532 & 3.9328 & 3.9328 & 3.9328 & 3.9328 & 3.9328 \\
\hline \multirow{4}{*}{$\begin{array}{l}\text { Business/ } \\
\text { strategic }\end{array}$} & Business sense & 7.3371 & 6.5922 & 6.5922 & 6.5922 & 6.5922 & 6.5922 \\
\hline & Customer concern & 1.9140 & 9.3389 & 9.3389 & 9.3389 & 9.3389 & 9.3389 \\
\hline & Integrative capability & 5.7421 & 11.5363 & 11.5363 & 11.5363 & 11.5363 & 11.5363 \\
\hline & Profit / cost consciousness & 3.1901 & 7.1415 & 7.1415 & 7.1415 & 7.1415 & 7.1415 \\
\hline
\end{tabular}

Exhibit 10: List of competencies and their importance score 
The matrices of required and available competencies

\begin{tabular}{|c|c|c|c|c|c|c|c|c|c|c|c|c|c|}
\hline \multicolumn{2}{|c|}{ Competencies } & \multirow{2}{*}{$\begin{array}{c}\mathrm{P} 1 \\
3\end{array}$} & \multirow{2}{*}{$\frac{\mathrm{P} 2}{4}$} & \multirow{2}{*}{$\frac{\mathrm{P} 3}{3}$} & \multirow{2}{*}{$\frac{\mathrm{P} 4}{4}$} & \multirow{2}{*}{$\frac{\mathrm{P} 5}{3}$} & \multirow{2}{*}{$\begin{array}{c}\text { P6 } \\
3\end{array}$} & \multirow{2}{*}{$\begin{array}{c}\mathrm{PM} \\
\mathrm{A}\end{array}$} & \multirow{2}{*}{$\begin{array}{c}\mathrm{PM} \\
\mathrm{B} \\
4\end{array}$} & \multirow{2}{*}{$\begin{array}{c}\text { PM } \\
\mathrm{C} \\
5\end{array}$} & \multirow{2}{*}{$\begin{array}{c}\text { PM } \\
\text { D } \\
5\end{array}$} & \multirow{2}{*}{$\begin{array}{c}\text { PM } \\
\text { E } \\
3\end{array}$} & \multirow{2}{*}{$\begin{array}{r}\text { PN } \\
\text { F } \\
3\end{array}$} \\
\hline Technical & $\begin{array}{l}\text { Knowledge of product } \\
\text { applications }\end{array}$ & & & & & & & & & & & & \\
\hline \multirow{5}{*}{$\begin{array}{l}\text { Administrative/ } \\
\text { process }\end{array}$} & Monitoring/control & 5 & 3 & 5 & 5 & 3 & 4 & 4 & 5 & 5 & 5 & 3 & 3 \\
\hline & Risk management & 5 & 4 & 5 & 5 & 3 & 4 & 4 & 5 & 5 & 5 & 4 & 3 \\
\hline & Planning/scheduling & 5 & 4 & 5 & 5 & 3 & 5 & 5 & 5 & 5 & 5 & 4 & 3 \\
\hline & Resource management & 3 & 3 & 3 & 3 & 3 & 4 & 4 & 4 & 5 & 5 & 4 & 3 \\
\hline & $\begin{array}{l}\text { Company's project } \\
\text { management process }\end{array}$ & 4 & 4 & 4 & 4 & 4 & 3 & 3 & 5 & 5 & 3 & 3 & 3 \\
\hline \multirow{5}{*}{ Intrapersonal } & Responsible & 4 & 4 & 4 & 4 & 4 & 5 & 5 & 4 & 5 & 5 & 4 & 3 \\
\hline & Proactive and ambitious & 4 & 4 & 4 & 4 & 4 & 2 & 2 & 4 & 5 & 5 & 4 & 3 \\
\hline & Mature and self-controlled & 4 & 4 & 4 & 4 & 4 & 3 & 3 & 5 & 5 & 5 & 5 & 3 \\
\hline & Organized and disciplined & 4 & 4 & 4 & 4 & 3 & 5 & 5 & 5 & 5 & 5 & 3 & 3 \\
\hline & Flexible & 5 & 5 & 5 & 5 & 5 & 2 & 2 & 5 & 5 & 5 & 5 & 3 \\
\hline \multirow{6}{*}{ Interpersonal } & Leadership & 5 & 5 & 4 & 4 & 3 & 3 & 3 & 5 & 5 & 5 & 4 & 3 \\
\hline & Communication & 4 & 4 & 4 & 4 & 4 & 2 & 2 & 5 & 5 & 5 & 4 & 3 \\
\hline & Conflict management & 4 & 4 & 4 & 4 & 4 & 1 & 1 & 3 & 5 & 5 & 4 & 3 \\
\hline & Team management & 3 & 3 & 3 & 4 & 3 & 2 & 2 & 3 & 5 & 5 & 4 & 3 \\
\hline & Negotiation & 4 & 4 & 4 & 4 & 4 & 4 & 4 & 5 & 5 & 5 & 3 & 3 \\
\hline & Problem solving & 4 & 4 & 4 & 4 & 4 & 4 & 4 & 5 & 5 & 5 & 4 & 3 \\
\hline \multirow{4}{*}{$\begin{array}{l}\text { Business/ } \\
\text { strategic }\end{array}$} & Business sense & 3 & 3 & 3 & 3 & 3 & 5 & 5 & 5 & 5 & 5 & 3 & 3 \\
\hline & Customer concern & 4 & 4 & 4 & 4 & 4 & 3 & 3 & 4 & 5 & 5 & 4 & 3 \\
\hline & Integrative capability & 4 & 3 & 3 & 5 & 3 & 4 & 4 & 5 & 5 & 5 & 4 & 3 \\
\hline & Profit / cost consciousness & 5 & 5 & 5 & 5 & 5 & 5 & 5 & 5 & 5 & 5 & 4 & 3 \\
\hline
\end{tabular}

\section{The correspondence matrix}

\begin{tabular}{c|cccccc}
\hline $\boldsymbol{W}_{\boldsymbol{i j}}$ & P1 & P2 & P3 & P4 & P5 & P6 \\
\hline PM A & 59.7 & 63.4 & 63.9 & 54.6 & 76.1 & 71.9 \\
PM B & 97.8 & 97.8 & 97.8 & 95.6 & 97.8 & 97.8 \\
PM C & 100.0 & 100.0 & 100.0 & 100.0 & 100.0 & 100.0 \\
PM D & 99.3 & 99.3 & 99.3 & 99.3 & 99.3 & 99.3 \\
PM E & 80.3 & 87.2 & 84.5 & 77.4 & 96.5 & 95.7 \\
PM F & 47.2 & 57.1 & 54.3 & 42.2 & 77.8 & 65.5 \\
\hline
\end{tabular}

\section{Exhibit 11: The competency matrices}




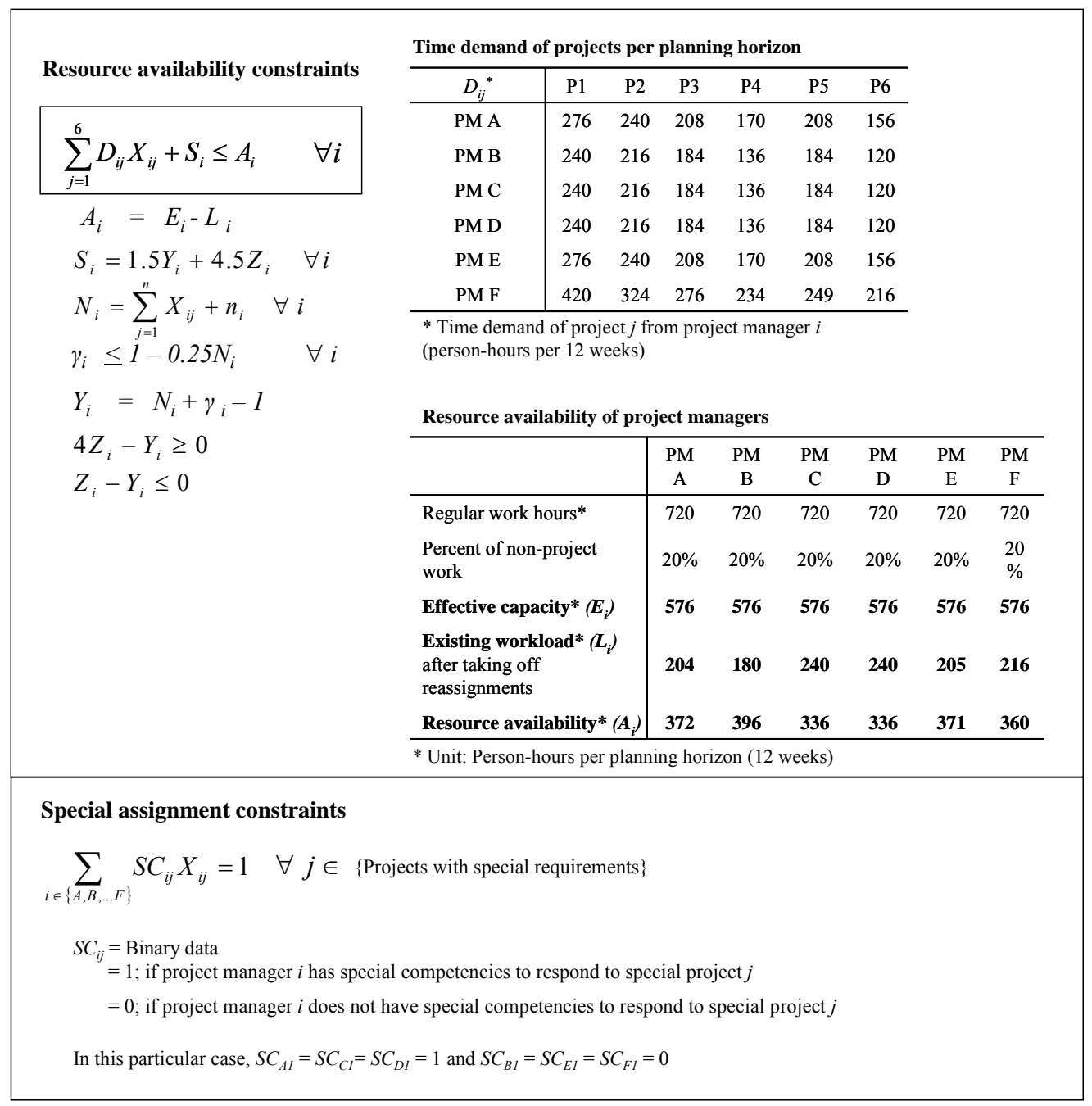

Exhibit 12: Resource availability and special assignment constraints 


$$
\operatorname{Max} \sum_{i \in\{A, B, \ldots F)} \sum_{j=1}^{6} \sum_{k=1}^{4}\left(\alpha_{i j k} G_{k} V_{j k} W_{i j} X_{i j}\right) \quad \text { Objective function }
$$

Subject to:

$$
\begin{array}{cl}
\sum_{j=1}^{6} D_{i j} X_{i j}+S_{i} \leq A_{i} \quad \forall i & \text { Resource availability constraints } \\
A_{i}=E_{i}-L_{i} & \\
S_{i}=1.5 Y_{i}+4.5 Z_{i} \quad \forall i & \\
N_{i}=\sum_{j=1}^{n} X_{i j}+n_{i} \quad \forall i & \\
\gamma_{i} \leq 1-0.25 N_{i} \quad \forall i & \\
Y_{i}=N_{i}+\gamma_{i}-1 & \\
4 Z_{i}-Y_{i} \geq 0 & \\
Z_{i}-Y_{i} \leq 0 & \\
\sum_{i \in\{A, B, \ldots F\}} S C_{i j} X_{i j}=1 \quad \forall j \in{ }_{\text {special requirements }\}} & \text { Special assignment constraints } \\
\sum_{i \in\{A, B, \ldots F\}} X_{i j}=1 \quad \forall j & \text { Project assignment constraints } \\
\sum_{i \in\{A, B, \ldots F\}} X_{i j}=1 \quad \forall i & \text { Project manager assignment constraints } \\
X_{i j}, \gamma_{i}, Z_{i} &
\end{array}
$$

\section{Resource availability constraints}

Results from model execution

\begin{tabular}{c|cccc}
\hline & Assignments & Total demand* & $\begin{array}{c}\text { Total number } \\
\text { of projects }\end{array}$ & $\begin{array}{c}\text { Resource availability } \\
\text { after assignments }^{\dagger}\end{array}$ \\
\hline PM A & Project 3 & 280 & 2 & 164 \\
PM B & Project 2 & 288 & 2 & 180 \\
PM C & Project 1 & 312 & 2 & 96 \\
PM D & Project 4 & 208 & 2 & 200 \\
PM E & Project 6 & 228 & 2 & 215 \\
PM F & Project 5 & 276 & 2 & 84 \\
\hline
\end{tabular}

* Includes project time demand and switching-over time loss. Unit: Person-hours per planning horizon (12 weeks) ${ }^{\dagger}$ Unit: Person-hours per planning horizon (12 weeks)

Exhibit 13: An optimization model for project manager assignment and its results 


\begin{tabular}{c|c|c|c|c|c|c|c|c|c}
\hline \multirow{2}{*}{$\alpha_{i j k}$} & \multicolumn{4}{|c|}{ Project 1 } & $\ldots$ & \multicolumn{4}{c}{ Project n } \\
\cline { 2 - 10 } & Goal 1 & Goal 2 & $\ldots$ & Goal o & $\ldots$ & Goal 1 & Goal 2 & $\ldots$ & Goal o \\
\hline Project manager 1 & $\alpha_{111}$ & $\alpha_{112}$ & & $\alpha_{11 \mathrm{o}}$ & & $\alpha_{1 \mathrm{n} 1}$ & $\alpha_{1 \mathrm{n} 2}$ & & $\alpha_{1 \mathrm{no}}$ \\
\hline$\ldots$ & & & & & & & & & \\
\hline Project manager $\mathrm{m}$ & $\alpha_{\mathrm{m} 11}$ & & & $\alpha_{\mathrm{m} 1 \mathrm{o}}$ & & $\alpha_{\mathrm{mn} 1}$ & & & $\alpha_{\mathrm{mno}}$ \\
\hline
\end{tabular}

Exhibit A1: Coefficients of effectiveness in discontinuity management in a project 


\begin{tabular}{l|l|l|l|l|l}
\hline \multicolumn{2}{l|}{ Competencies } & $\mathrm{P}$ & $\mathrm{P}$ & $\ldots$ & $\mathrm{P}$ \\
\hline \multirow{2}{*}{ Technical } & Knowledge of prod. app. & & & & \\
\hline & $\ldots$ & & & & \\
\hline \multirow{2}{*}{$\begin{array}{l}\text { Admin./ } \\
\text { process }\end{array}$} & Monitoring and control & & & & \\
\hline \multirow{2}{*}{$\begin{array}{l}\text { Intra- } \\
\text { personal }\end{array}$} & $\ldots$ & & & & \\
\hline \multirow{2}{*}{$\begin{array}{l}\text { Inter- } \\
\text { personal }\end{array}$} & $\ldots$ & & & & \\
\hline $\begin{array}{l}\text { Business/ } \\
\text { strategic }\end{array}$ & $\ldots$ & & & & \\
\hline \multicolumn{2}{l}{$\mathrm{P}=$ Project } & $\ldots$ & & & \\
\hline & Business sense & & & & \\
\hline
\end{tabular}

Exhibit A2: The matrix of required competencies 


\begin{tabular}{|c|c|c|c|c|c|}
\hline \multicolumn{2}{|r|}{ Competencies } & PM & $\overline{\mathrm{PM}}$ & $\ldots$ & $\overline{\mathrm{PM}}$ \\
\hline \multirow{2}{*}{ Technical } & Knowledge of prod. app. & & & & \\
\hline & & & & & \\
\hline \multirow{2}{*}{$\begin{array}{l}\text { Admin./ } \\
\text { process }\end{array}$} & Monitoring and control & & & & \\
\hline & $\ldots$ & & & & \\
\hline \multirow{2}{*}{$\begin{array}{l}\text { Intra- } \\
\text { personal }\end{array}$} & Organized and disciplined & & & & \\
\hline & $\ldots$ & & & & \\
\hline \multirow{2}{*}{$\begin{array}{l}\text { Inter- } \\
\text { personal }\end{array}$} & Leadership & & & & \\
\hline & $\ldots$ & & & & \\
\hline \multirow{2}{*}{$\begin{array}{l}\text { Business/ } \\
\text { strategic }\end{array}$} & Business sense & & & & \\
\hline & & & & & \\
\hline
\end{tabular}

Exhibit A3: The matrix of available competencies 


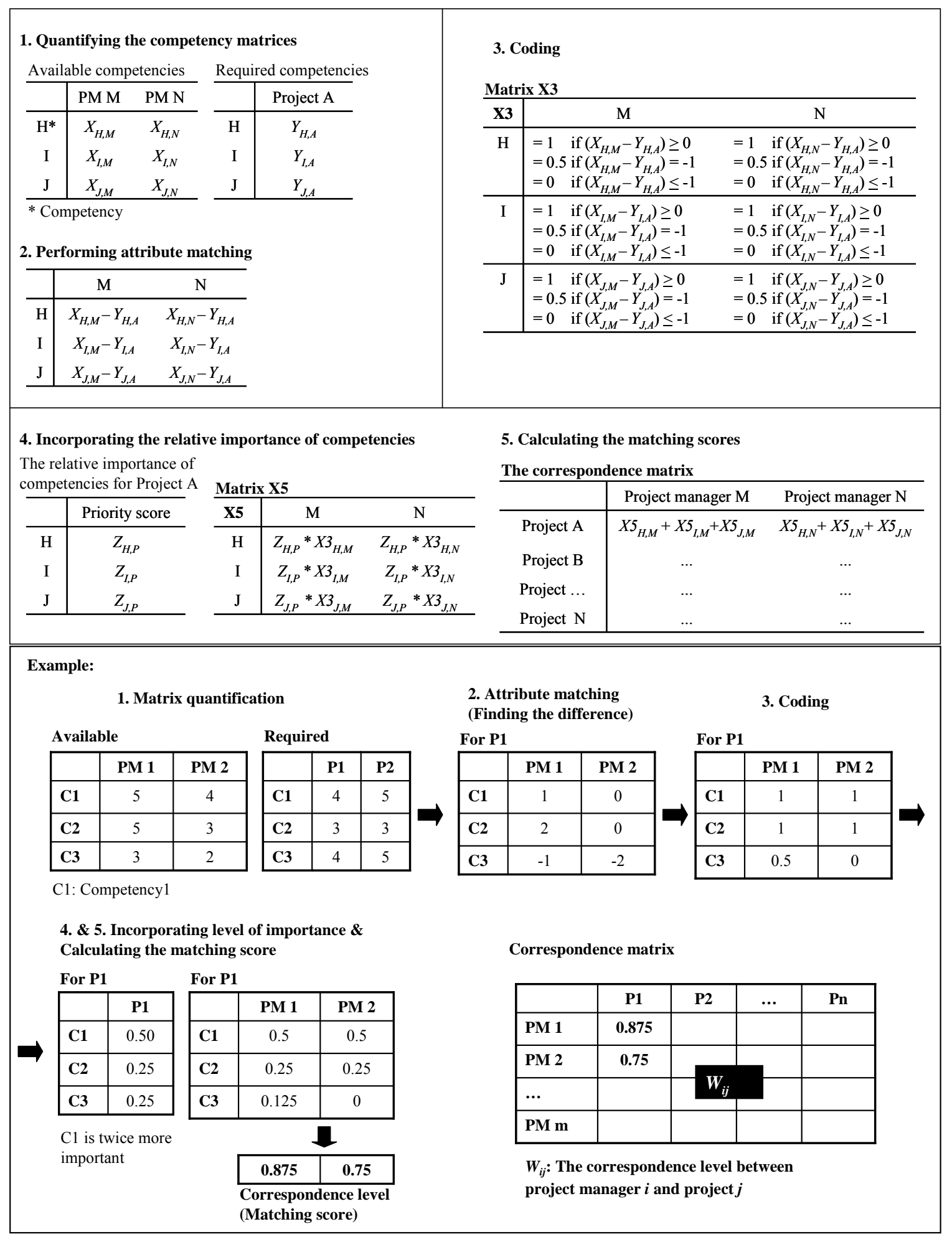

Exhibit A4: Steps for the quantification of $W_{i j}$ 